\title{
Who Wrote the Trisvabhāvanirdeśa? Reflections on an Enigmatic Text and Its Place in the History of Buddhist Philosophy
}

\author{
Matthew T. Kapstein \\ École Pratique des Hautes Études, Paris, and \\ The University of Chicago
}

\begin{abstract}
In recent decades, scholars of Buddhist philosophy have frequently treated the Trisvabhävanirdeśa (TSN), or "Teaching of the Three Natures," attributed to Vasubandhu, as an authentic and authoritative representation of that celebrated thinker's mature work within the Yogācāra tradition. However, serious questions may be posed concerning the status and authority of the TSN within Yogācāra, its true authorship, and the relation of its contents to trends in early Yogācāra thought. In the present article, we review the actual state of our knowledge of the TSN's possible origins, considering, too, the implications this may have for contemporary treatments thereof.
\end{abstract}

\author{
$* * *$ \\ "Everyone knows Vasubandhu. \\ What is remarkable, then, is that we do not, by now, know Vasubandhu very well."
}

\section{Introducing the Trisvabhāvanirdeśa}

The present reflections stem from an "a-ha!" moment that occurred to me not long ago. I was just finishing a draft translation of the Trisvabhāvanirdeśa (TSN), or "Teaching of the Three Natures," attributed to Vasubandhu, when I was struck by the thought, "this could not possibly be by Vasubandhu." I was startled by this, for, though reservations about the text have been expressed from time to time, ${ }^{2}$ its authenticity has been widely accepted and, like many others in this field of study, I concurred with the consensus view.

I was therefore concerned to determine whether my "a-ha!" moment was possibly a genuine insight, or merely an instance of lunacy induced, perhaps, by the mental fatigue of having just translated a bunch of Sanskrit. Herein I shall attempt to work this out, and, basing myself on the preponderance of the evidence, I believe that the credentials of the text must now be considered to be extremely doubtful. ${ }^{3}$

The TSN was introduced to modern scholarship by one of the great pioneers of Yogācāra studies, Sylvain Lévi, who transmitted a copy of a manuscript he found in Nepal in 1928 to his Japanese student Susumu Yamaguchi. The latter edited the Sanskrit text together with a Tibetan translation and published it in the Japanese Journal of Religious Studies (Shükyo $k e n k y \bar{u}$ ) in $1931 .{ }^{4}$ A few years later, Louis de La Vallée Poussin, considering the near unavailability of Yamaguchi's work outside of Japan and the fact that the latter failed to note 
that there were indeed two Tibetan translations of the TSN, not just the one he had published, edited the Sanskrit text anew, together with both Tibetan versions and his own French translation; his work appeared in the Mélanges chinois et bouddhiques in 1933. ${ }^{5}$ At about the same time, Giuseppe Tucci obtained another copy of the original manuscript and entrusted it to Sujitkumar Mukhopadhyaya at the Shantiniketan, who in 1939 published a monograph devoted to it in the Visvabharati series, including the Sanskrit text, both Tibetan versions, an English translation, and, most valuably, an anthology of parallel passages that he culled from varied sources such as the Lañkāvatārasūtra (LAS), the Mahāyānasūtrālamkāra (MSA), the Madhyāntavibhāga (MAV), and the Māndūkyopanișad with the Gaudapādakārikā. ${ }^{6}$ To the best of my knowledge, all subsequent editions of the text - including those by Anacker (2005 [1984]), Chatterjee (1971), Chogḍu (i.e., Thub-bstan-mchog-grub) and Tripathi (1972), and Tola and Dragonetti (1983) - were ultimately based on these publications of the 1930s. A photographic reproduction of the original Sanskrit manuscript preserved in the National Archives of Nepal became widely available in 1989 through the efforts of Mimaki, Tachikawa, and Yuyama. Although it does not lead us fundamentally to reconsider the Sanskrit text as established through the earlier editions, it does help to clarify some points of detail. ${ }^{7}$ The colophon of the Sanskrit manuscript, a palm-leaf dating to about the twelfth century, explicitly attributes the text to Vasubandhu: krtir ācāryavasubandhupādānām iti. ${ }^{8}$

As La Vallée Poussin and Mukhopadhyaya both noted, one of the two Tibetan translations, by the well-known eleventh-century Tibetan translator 'Gos Khug-pa Lhas-btsas working in collaboration with the pandita Sāntibhadra, also attributes the text to Vasubandhu. ${ }^{9}$ The second Tibetan translation was the work of a Kashmiri scholar named Candrakīrti (Tib. Zla-ba-grags-pa), who was also the author of a short Mādhyamika tract preserved in in the Tanjur, the *Madhyamakaprajñāvatāra, that, interestingly, he translated in collaboration with the same 'Gos Khug-pa Lhas-btsas just mentioned. ${ }^{10}$ His rendition of the TSN, however, gives the the title of the work as *Trisvabhāvapraveśasiddhi (Tib. rang bzhin gsum la 'jug pa sgrub pa), the "Attainment of Penetration of the Three Natures,"11 and names the author of the text as Nāgārjuna. Besides this, it differs from the first version primarily by the interpolation of two verses, as well as in points of syntactic detail. ${ }^{12}$ La Vallée Poussin and Mukhopadhyaya both argued that, because the contents of the text evidently focus upon distinctive Yogācāra doctrines and not Madhyamaka, the attribution to Nāgārjuna could be safely eliminated and Vasubandhu therefore accepted as the author. ${ }^{13}$ In this they have been generally followed in subsequent scholarship. What they and others have tended to overlook is that the choice between Nāgārjuna and Vasubandhu was never a simple binary; there were other ways of reading the evidence to which I shall return below.

In keeping with the attribution of the TSN to Vasubandhu, Anacker and some others have adopted a notably robust view of where it is to be situated in the corpus of that prolific author's work, holding it to have been a late composition and sometimes even asserting it to have been Vasubandhu's "last work." "I I have no idea of how a periodization of such precision can be justified. ${ }^{15}$ In all events, the subject-matter of the text, the "three natures" 16 theory of Yogācāra Buddhism, that is to say, the analysis of reality in terms of the three categories of the "constructed," "conceptual," or "imagined" (parikalpita), the "dependent" or "heteronomous" (paratantra), and the "absolute" or "consummate" (parinispanna), is discussed elsewhere in the Vasubandhu corpus and so plausibly may have been amplified by him in a work specifically dedicated to it. ${ }^{17}$ There are therefore no obvious, prima facie grounds for rejecting Vasubandhu's supposed authorship out of hand. 
On the contrary, the TSN has been treated in recent scholarship as one of Vasubandhu's key contributions to Yogācāra thought. At least seven English translations have been published in a little over three decades, ${ }^{18}$ and it is frequently cited as an authority in discussions of Vasubandhu's philosophy. ${ }^{19}$ The TSN is an established foundation stone upon which the interpretive enterprise in this area of Buddhist Studies is thought to be securely based.

Despite this, the transmission and reception history of the TSN are troubling. The text is nowhere cited, so far as we know, in any Indian work, Buddhist or otherwise.

The sole Sanskrit manuscript dates to three-quarters of a millennium after Vasubandhu's time ${ }^{20}$ a common enough situation in Indian textual histories, though, given the absence of citation, ${ }^{21}$ there are reasons to regard this as problematic in the present case. It was never translated into Chinese, despite the intensive Chinese interest in Vasubandhu's writings, nor is it known to be mentioned in traditional Chinese Buddhist sources. ${ }^{22}$ It was not translated into Tibetan by the translation committees of the imperial period during the eighth and ninth centuries, which devoted much attention to the Vasubandhu corpus, ${ }^{23}$ but reached Tibet only during the eleventh century, that is to say, not far from the period during which the extant Sanskrit manuscript was created. Traditional accounts of Vasubandhu known in Tibet do not enumerate it in their lists of his works, ${ }^{24}$ although of course it appears regularly in catalogues of the Tanjur. ${ }^{25}$ Indeed, despite the availability of the TSN in Tibet, the text seems to have been a matter of general indifference to Tibetan doctrinal authors; I have located so far only two writers, though there may well be others I have missed, who clearly cite it: Bcom-ldan Rig-pa'i ral-gri (1227-1305) on two occasions in his commentary on Śāntarakșita's Madhyamakālamkāra; ${ }^{26}$ and Tāranātha (1575-1634), who refers to the version attributed to Nāgārjuna once in his longer commentary on the Heart Sūtra. ${ }^{27}$ Oddly, though the latter also mentions just the title of the Tibetan version attributed to Vasubandhu in his History of Indian Buddhism, he credits Asanga there with its composition. ${ }^{28}$

These considerations, taken together, certainly do not suffice for us to reject definitely the attribution of the work to Vasubandhu, but they do suggest the need for circumspection about it.

\section{Which Vasubandhu? Whose Vasubandhu?}

Before proceeding any further in our consideration of the TSN, we need to clarify so far as possible just what we mean when we attribute a text to Vasubandhu. Buddhist Studies have, for over a century, performed artful contortions in respect to the "Vasubandhu problem." Is this the name of a unique author, or of two, or perhaps even more? If more than one, then how are the works attributed to this figure to be apportioned amongst them? Are we to imagine a simple division between Yogācāra and non-Yogācāra writings, or is the situation more complicated, involving perhaps the attribution of some Yogācāra works to each of the two or more authors concerned? And which of these figures is the teacher known to the hagiographical tradition in both China and Tibet as Asanga's half-brother? What are the implications of all this for dating and reception? And so it goes. I do not intend to rehearse here the entire issue, but will limit my remarks to touch upon just a few salient points in order to clarify my own position in our present context.

In recent decades, most scholars in this area have tended to opt for one of two alternatives: either the hypothesis that there were two major doctrinal authors named 
"Vasubandhu," or the rejection of this in favor of single authorship, as is generally affirmed by tradition. ${ }^{29}$ Those who have favored the two Vasubandhu view have emphasized several sorts of evidence: the explicit mention by Yaśomitra and by Sthiramati of a Vasubandhu who was active prior to the author known as the kośakāra, that is, the author of the Abhidharmakośa (ADhK) and its bhāṣya (ADhKBh); cross references among the works attributed to the kośakâra, making it plausible to consider these as forming a coherent group of texts, distinct from other parts of the Vasubandhu corpus $;{ }^{30}$ and, more impressionistically, a variety of stylistic and doctrinal features that seem to militate against identifying the author of the $\operatorname{ADhK}(\mathrm{Bh})$ with the figure(s) responsible for these other works, including the

Mahāyānasūtrālaṃkārabhāşya (MSABh), the Madhyāntavibhāgabhāṣya (MAVBh), and the Daśabhūmikasütravyākhy $\bar{a} .{ }^{31}$ Nevertheless, it is now widely recognized that very broad doctrinal similarities and differences must be treated with particular care, for a consensus of sorts has emerged that the kośakāra was the author of Yogācāra works including the Vimiśikā and Trimisiki (Trmśs), as well as the Karmasiddhiprakaraṇa and the Vyākhyāyukti, among others. Skilling (2000), in particular, has very precisely presented the case favoring the common authorship of these and a number of other core texts. ${ }^{32}$ In contrast with Vasubandhu the kośakāra, Buescher and others speak of Vasubandhu the commentator, bhāsyakāra, an earlier writer who is presumed to have composed the MSABh and the MAVBh, and perhaps other Yogācāra commentarial works as well. ${ }^{33}$ To date, however, the basis for the single authorship of works ascribed to the bhassyakāra has not been so firmly grounded; the philosophical and literary identity of the kośakâra seems now to be better understood. This is a point to bear in mind in what follows.

Some considerations, however, suggest that the "two Vasubandhus" theory may be problematic. ${ }^{34}$ A point of particular interest, to my mind, is the puzzling position of Sthiramati in respect to the question. For this figure, perhaps the most notable commentator on the Vasubandhu corpus overall, wrote prolifically on works included among the writings - following here the view that holds there to have been two major Vasubandhus - of both the bhāsyakāra and the kośakāra, without, so far as we know, distinguishing them as separate authors. Sthiramati nevertheless does mention, in his commentary on the ADhK, an elder Vasubandhu, who, as Skilling has shown, seems to have been an earlier äbhidharmika and thus not (or at least not identifiably) the bhāsyakāra. ${ }^{35}$ This consideration may perhaps be thought to problematize Buescher's argument in regard to the distinction between the bhāsyakāra and the kośakāra, though it is in fact very far from disproving it; for it is the treatment of the two Vasubandhus as one that now stands in need of explanation. In all events, without crediting traditional assertions that Sthiramati was Vasubandhu's direct disciple, he was not likely just to have confused two quite distinct figures, particularly given that he was clearly aware of at least one other Vasubandhu and so appears not to have been indiscriminately conflating different persons of this name. ${ }^{36}$ I ignore here questions recently raised by Kramer concerning the common authorship of all that is attributed to Sthiramati, which add another layer of complexity to the problem, but, even still, the fact that the "Sthiramati corpus" nowhere seems to have distinguished the bhāsyakāra from the kośakāra is not, I think, to be considered as lacking in relevance. ${ }^{37}$

We find ourselves, then, in an aporetic situation: Vasubandhu can neither be two nor one. (Not to mention both or neither ... ) Is there before us a way to escape from this impasse ${ }^{38}$

I believe that we might do well to take a cue from our colleagues in medieval and renaissance art history. It is not at all unusual to find, for example, that one work may be 
quite certainly assigned to Bruegel, another merely attributed to him, a third credited to his workshop, a fourth to a follower or to his school, yet another may be determined to be a copy, while finally there are those works judged to be outright fakes. Authorship proves here to be a fuzzier category than we Buddhologists often hold it to be; authenticity is separated from falsehood by a range of intermediary degrees and not by a simple binary division. And Bruegel, in particular, makes a good example in our present context, for we know that, just as there were a number of figures named "Vasubandhu," so too the Bruegels: the major artists thus named include Pieter the Elder, his sons Pieter the Younger and Jan the Elder, and the latter's son Jan the Younger. Although all four were distinguished painters in their own right, the lines between them have been sometimes blurred; the workshop of Pieter the Younger, for instance, made much of its bread and butter imitating paintings by Pieter the Elder, whose work, however, is quite distant from that of his grandson Jan the Younger. A vast Indrajāla would be required to describe the many ways in which these four were interrelated not just with one another, but with innumerable contemporaries and successors as well. Popular accounts, of course, continue to dwell upon the solitary bright stars in the artistic firmament, but art historical research turns its attention to more complex and messy galactic formations.

My sense is that something like an art historical perspective is what is required in treating of several of the major Indian Buddhist masters. This suggestion is by no means novel. In an entry in his notebook dating to 1959, the British bhikkhu and Pali translator Nānamoli remarked that "Buddhaghosa" names a committee. ${ }^{39}$ In the case that concerns us here, Hidenori Sakuma has recently elaborated a proposal along similar lines in reference to Asanga and Vasubandhu, noting that "questions concerning authorship that one might seek to establish definitively from a modern perspective had little meaning for Indian yoga practitioners of yore." ${ }^{, 40}$ While such an approach permits us to grant full weight to the considerations that favor the view that there were at least two important Vasubandhus - the bhāṣyakāra and the kośakāra-it permits us to affirm at the same time that the kośakära came both to enjoy a particular prominence and to have been related by varying degrees of distance to the sprawling corpus created over a period of two or three generations by the larger community of Buddhist masters of which he was part and among whom "Vasubandhu" was not a unique name. We may continue to speak of the group of core texts of which we believe him to have been the unique author-the works attributed to the kośakära by Schmithausen and Skilling are likely those that belong here. A second circle would be occupied by the many works that noticeably depart from the core texts in matters of usage, style, or doctrine, but which nevertheless may have been composed, edited, collated, or redacted as part of the vast project, sometimes thought of as the "Mahāyāna Abhidharma," in which Asanga and Vasubandhu are named among the key movers. The works Buescher has assigned to the bhäsyakāra figure among those classed here. These two circles, taken together, constitute the larger "Vasubandhu corpus." For it is possible, I believe, that the kośakära and his students were instrumental in the redaction and transmission of this corpus, including the works of the bhassyakāra. This would go a long way towards explaining the subsequent treatment, within the tradition, of the diverse Vasubandhu writings as the works of a single author.

This approach, however, still may not account for all that was attributed to Vasubandhu at one time or another; we must accept the possibility that there were sometimes mistaken ascriptions involving writings that had no real connection to Vasubandhu and his circle, works that must be classed as the Vasubandhu pseudepigrapha. As concerns the TSN, therefore, it is necessary that we refine our question in the light of such considerations to ask whether the text is to be included among the core writings of the kośakara, or if it was more 
likely a product of the larger Vasubandhu corpus, including the commentaries of the bhassyakāra, that was formed during the fourth and fifth centuries, or, finally, if it is to be ruled out of court altogether.

For convenience, however, in what follows I shall usually continue to speak of Vasubandhu in the singular. When I do, readers may take me to be referring indifferently to the author(s) of the fourth-fifth century "Vasubandhu corpus," though I shall also have occasion to designate specific parts of this broad Vasubandhu corpus in some instances with greater precision.

\section{Philological and Doctrinal Considerations}

\section{$k h y \bar{a}$, "to appear"}

On reading the TSN in the original Sanskrit, one is particularly struck by the frequent use of forms of the verb khya, without prefix, in the meaning "to appear, manifest," always rendered snang in Tibetan. In the 38 verses of the Sanskrit text, this occurs twelve times. ${ }^{41}$ And the author is quite systematic in his usage. In verses 2 and 3, in particular, the three natures are defined in terms of it:

$$
\begin{aligned}
& \text { yat khyāti paratantro 'sau yathā khyāti sa kalpitạh } \\
& \text { pratyayādhīnavrttitvāt kalpanāmātrabhāvataḥ || TSN } 2 \\
& \text { tasya khyātur yathākhyānaṃ yā sadāvidyamānatā } \\
& \text { jũeyah sa pariniṣpannasvabhāvo 'nanyathātvatah || TSN } 3
\end{aligned}
$$

What appears $(k h y \bar{a} t i)$ is heteronomous and the manner in which it appears $(k h y \bar{a} t i)$ is conceptually constructed; for [the one] occurs dependent on conditions, while [the other] has its being merely in thought. || TSN 2

The perpetual absence of what appears in the way it appears (tasya khyatuh yathäkhyānam) should be known to be the consummate nature, by virtue of [its] inalterability. || TSN 3

Now, although this does not seem to have been given sustained attention in earlier publications on the TSN, this usage is unusual. Indeed, while the root khya is prolific in its prefixed derivations - $\bar{a} k h y \bar{a}$, "to explain, tell," vyākhy $\bar{a}$, "to comment," samkhyya, "to think, enumerate," pratisamkhyā, "to ponder, investigate," and many more-the use of khya alone is quite rare in early materials and this is reflected in the uncertainty expressed, among the lexicographers, about precisely how it is to be understood. Böhtlingk and Roth, for instance, tell us that "Die Grundbedeutung scheint schauen zu sein"42 - "the fundamental meaning seems to be (emphasis added) to perceive"-while Monier-Williams, following Böhtlingk and Roth, tells us that "the simple verb [i.e. khyäti] occurs only in Pass[ive] and Caus[ative]," which is to say that, although khyāti is theoretically permitted it does not in fact occur; instead we find forms such as khyāyate, meaning "to be named, known," and khyapayati, "to make known." ${ }^{\text {"33 }}$ The use of khya we find in the TSN, in other words, is unknown to the most important European Sanskrit dictionaries. 
Khy $\bar{a}$ in the meaning "to appear," however, is not altogether exceptional. While medieval Sanskrit lexicons, such as the Amarakośa (5th-7th c.), do not seem familiar with this sense of the verb, ${ }^{44}$ late lexical works indeed are; the 19th c. Väcaspatyam, for example, specifies that one of the meanings of khyā is prakäśana, "appearance, manifestation." And in Vedānta texts, beginning no later than Śankara, we often find khyāti-here used as a noun and not a verb - in the sense of "knowledge of appearances" as opposed to true, ultimate knowledge. ${ }^{46}$ This usage gives rise to the important philosophical topic of khyātivāda, "theories of false knowledge," which form the basis for a widespread way of classifying philosophical schools $;^{47}$ one finds it invoked not only throughout later Advaita-Vedānta, but in the works of philosophers belonging to other traditions as well, such as the great 11th c. Digambara Jain philosopher Prabhācandra. ${ }^{48}$ These developments, however, take place long after Vasubandhu's time and so do not shed much light on the terminology we find in the TSN, at least if we think of it as a work by Vasubandhu.

Nevertheless, some precedents for the usage of the TSN are to be found in Buddhist works and it now seems likely to me that khyā was in fact first used to mean "to appear" in Buddhist sources. But we must note that this is nevertheless foreign to the diction of the core writings of Vasubandhu. For instance, in the Abhidharmakośa and its commentary, there are no fewer than 183 occurrences of derivatives of $k h y \bar{a}$, none in the sense that is relevant to us here. ${ }^{49}$ It occurs not at all in the Viṃsiki $\bar{a}$ and its autocommentary, nor in the Trimssikika (Trmś), though in Sthiramati's commentary on the latter, the Trimśatikābhāsya (TrBh) we do find six occurrences of khya, once in the meaning of "appearing." On this occasion, however, it is used with the prefix pra-, which is unexceptional. ${ }^{50}$ So, if this is not Vasubandhu the kośakāra's usage, whose is it? Examining the instances of khyā meaning "to appear" in a range of relatively early works may help to clarify what is at issue.

In the Bodhisattvabhümi (BBh), among 116 occurrences of derivatives of khy $\bar{a}$ throughout the work overall, on four occasions, all in the Bodhipaksyapatala, we find the finite verbs khyāti and khyānti in the meaning "appears." These are the earliest occurences of this usage that I have been able to document so far, and it is of course significant that this is found in a Yogācāra text, one with which Vasubandhu was surely familiar. All four instances are found on the same page (181) of the BBh in Dutt's edition, the last two as follows:

tadyathā māyā na ca yathā khyāti tathāsti / na ca punah sarvenaiva sarvam nāsti tanmāyākrtam / evam na caite dharmā yathaivābhilāpasamstavavaśena khyānti bālānām tathaiva saṃvidyante /

"[A]n illusion is something that does not truly exist in the way that it appears. Nor is an object that is created by a magical illusion something that is completely and totally nonexistent. Similarly, entities do not truly exist in the way that they appear to immature beings by the power of their habituation to expressions." ${ }^{, 51}$ (emphasis added)

It is, however, in another work that is closely associated with the $\mathrm{BBh}$, that we find this usage developed in relatively close connection with discussions of the three natures. The text in question is the MSA together with the MSABh, a commentary attributed to Vasubandhu (i.e., the bhāsyakāra). In this case, of 80 uses of khyā throughout the work, some 24 must be taken to refer to appearance, manifestation or similar ideas. ${ }^{52}$ We read, for instance, in the eleventh chapter:

yathājalpārthasamjjāāyā nimittam tasya vāsanā | 
tasmād apy arthavikhyānaṃ parikalpitalakṣaṇam || MSA 11.38

lakșaṇam samāsena trividham parikalpitādilakṣaṇam | tatra parikalpitalakṣaṇam trividham yathājalpārthasamjjñāyā nimittam tasya jalpasya vāsanā tasmāc ca vāsanād yo 'rthah khyāti avyavahārakuśalānām vināpi yathājalpārthasamjñayā. [...]

yathānāmārtham arthasya nāmnah prakhyānatā ca yā | asamkalpanimittam hi parikalpitalakșanam || MSA 11.39

aparaparyāyo [...] yadi yathānāmārthah khyāti yathārtham vā nāma ity etad abhūtaparikalpālambanam parikalpitalakșanam etāvad dhi parikalpyate yad uta nāma vā artho veti $\mid$

The constructed mode is the sign consisting of a cognition of the accord of utterance and object, the disposition connected to that, as well as, due to that, the distinct appearance of the object. MSA 11.38

The modes, in brief are threefold: the constructed mode, etc. The constructed mode, in turn, is threefold: the sign consisting of a cognition of the accord of utterance and object; the disposition connected to that utterance; and the object that appears due to that disposition, or, in the case of those who are not competent in linguistic convention, without the cognition of the accord of utterance and object. [...]

The constructed mode, moreover, has as its sign misconceptualization, which is the appearance of object and of word as if there were accord of word and object. MSA 11.39

Another account: [...] Whether it is the object that appears in accord with the word, or the word in accord with the object, this, the constructed mode, has as its intentional object a construction of what is not. For conceptual construction extends just so far as there is so-called "name" or "object."

This is in some respects a difficult passage and there may well be disagreements with certain details of my interpretation. My concern, however, is just with the occurrences of $k h y \bar{a}$, together with $v i-k h y \bar{a}$ and pra-khya, that we find here. The Tibetan translation treats all three as synonyms in this case and so translates them uniformly as snang, "to appear, be manifest." Lévi suggests a distinction not of the essential meaning, but of nuance: he renders $k h y \bar{a}$ alone as apparaître, and qualifies vi-khyā as clarté and pra-khyā as éclairecissement. ${ }^{53}$ The recent English translation by Jamspal and others takes both khya and $v i-k h y \bar{a}$ to mean "perception," but treats pra-khyā in MSA 11.39 as "projection." although "appearance" remains key to the MSA's definitions of the second, heteronomous nature (paratantrasvabhāva) in the verses that immediately follow, the term of choice for this is no longer $k h y \bar{a}$ but rather $\bar{a} b h \bar{a} s a-$, an expression that never occurs at all in the TSN.

There is another passage in the MSA in which khya occurs with notable frequency, in the concluding verses of the section of the nineteenth chapter (on the virtues of the bodhisattva) concerned with the acquisition of "encompassing knowledge" (parijñana). Almost half of the relevant instances of $k h y \bar{a}$ throughout the MSA(Bh) are to be found in this one section alone:

tatvam samcchādya bālānām atatvam khyāti sarvataḥ | tatvam tu bodhisatvānām sarvatah khyāty apāsya tat || 19.53 
etena yathā bālānām svarasenātatvam eva khyāti nimittam na tatvam tathatā | evam

bodhisatvānām svarasena tatvam eva khyāti nātatvam ity upadarśitam |

akhyānakhyānatā jñeyā asadarthasadarthayoh |

àśrayasya parāvṛttir mokṣo 'sau kāmacāratah || 19.54

asadarthasya nimittasyākhyānatā sadarthasya tathatāyāh khyānatā āśrayaparāvṛttir veditavyā | tayā hi tad akhyānam khyānam ca $\mid$ saiva mokṣo veditavyah $\mid$ kị̣ kāraṇaṃ| kāmacāratah $\mid$ tadā hi svatantro bhavati svacittavaśavartī prakrtyaiva nimittāsamudācārāt |

anyonyam tulyajātīyaḥ khyāty arthah sarvato mahān |

antarāyakaras tasmāt parijñāyainam utsṛjet || 19.55

idam kṣetrapariśodhanopāye yathābhūtaparijñānam | bhājanalokārtho mahān anyonyam vartamānas tulyajātīyah khyāti sa evāyam iti | sa caivam khyānād antarāyakaro bhavati buddhakṣetrapariśuddhaye | tasmād antarāyakaram parijñāyainam utsṭjed evam khyātạ̣|

Reality being concealed to the childish, unreality appears all around. But to bodhisattvas, who have cast that off, it is reality that appears all around. 19.53

This shows that, as the characteristic that is not reality appears to the childish according to their sensibility, but not the reality that is thus-ness, just so, to bodhisattvas, according to their sensibility, it is reality that appears, but not unreality.

The non-appearance and appearance of the unreal object and the real object [respectively] should be known to be the 'inversion of the ground'. This is freedom, for [henceforth] one acts at will. 19.54

The non-appearance of the characteristic that is an unreal object and the appearance of the real object, thus-ness, should be known to be the inversion of the ground, for which reason there is non-appearance as well as appearance and just that should be known as freedom. Why so? Because one acts at will. One becomes autonomous then, master over one's mind and by nature unswayed by conditional characteristics.

The objective environment [lit. the 'great object'] appears everywhere, in mutual interrelations and of common type, and so forms an obstacle, wherefore it should be rejected with encompassing knowledge. 19.55

This concerns encompassing knowledge as the means of purifying the field. The great object of the world as environment appears as being of common type in its mutual interrelations, wherefore [all accept that] "this is just how things are." But due to that appearance it is an obstacle to the purification of buddha-fields. Therefore, through the encompassing knowledge of this obstacle, such appearance should be rejected.

A notable feature of $k h y \bar{a}$ as it is used here is that it refers not to superficial, deceptive appearance alone, but may apply as well to the appearance of reality in the purified experience of bodhisattvas. ${ }^{55}$ Nevertheless, taking account of these citations overall, we may propose that the MSA forms the likely background for much of the TSN. There are other reasons for drawing this conclusion as well. One is the use of the example of the illusory elephant in TSN 27-30 \& 33-the appearance of an elephant conjured up in a magic show. This is a wide-spread parable in Buddhist literature, and occurs not only in the TSN but also in both the MSA and the MAV: 
māyākrtam mantravaśāt khyāti hastyātmanā yathā

$\bar{a} k \bar{a}$ ramātram tatrāsti hastī nāsti tu sarvathā || TSN 27

svabhāvaḥ kalpito hastī paratantras tadākrtị |

yas tatra hastyabhāvo 'sau pariniṣpanna ișate || TSN 28

asatkalpas tathā khyāti mūlacittād dvayātmanā |

dvayam atyantato nāsti tatrāsty ākrtimātrakam || TSN 29

It is as, when owing to the power of a mantra, there appears an illusory product whose form is that of an elephant, there is merely a phenomenal feature and no elephant at all. (27)

The constructed nature is the elephant, the heteronomous the phenomenal feature, while the absence of the elephant there is held to be the absolute. (28)

Thus, from the mind that is the root an unreal construction dualistically appears. But the duality is definitely not, while what there is is merely the phenomenal feature. (29)

For comparison, consider now the same example as summarized in the commentaries on the MSA and MAV:

MSABh ad 11.15 yathā māya yantra[=mantra]parigrhìtam bhrāntinimittạ̣ kāșthaloștādikam tathābhūtaparikalpaḥ paratantrah svabhāvo veditavyah $\mid$ yathā māyākrtam tasyām māyāyām hastyaśvasuvarnāadyākrtis tadbhāvena pratibhāsitā, tathā tasminn abhūtaparikalpe dvayabhrāntir grāhyagrāhakatvena pratibhāsitā parikalpitasvabhāvākārā veditavy $\bar{a} \mid$

As an illusion [is conjured when] a mantra is applied to a stick, a pot, etc., that are the conditions for [perceptual] error, so one should know the heteronomous nature to be a conceptual construction. As the illusory product is the phenomenal form-elephant, horse, gold, or whatever - that is made to appear in that illusion by the force of that [conjuration], so, too, one should know that the phenomenal form that is of the nature of conceptual construction is the error of duality, made to appear within the conceptual construction of the unreal by force of the subject-object dichotomy.

MAVBh ad 5.17: yat tad arthasyāsatvam satvam cānantaram uktam/ tan māyādivan matạ yathā māyā na hastyādibhāvenāsti na ca naivāsti / tadbhrāntimātrāstitvāt /

The non-being and being of the object, as has been explained above, is thought to be like illusion and such. For an illusion qua existence, e.g., of an elephant, neither is nor is not, because it exists just insomuch as it is an error.

In these passages we note that, while the verb khya is introduced in this context only in the TSN, the diction is otherwise remarkably close to what we find in the MSA and its commentary in particular. 
In closing this section, we may add that $k h y \bar{a}$ in the sense of "appear" is frequently encountered in the Lankiavatärasütra, though its relation there with the three natures, besides parikalpita, is perhaps less clearly delineated than it is in either MSA or TSN. An innovation that we find in the LAV may be the expression khyätivijñana, "phenomenal consciousness," i.e. consciousness of ostensible appearances, a phrase that perhaps influenced subsequent Vedāntic usage. $^{56}$

Considered altogether, these observations on $k h y \bar{a}$ and its derivatives suggest that the author of the TSN adopted a lexical register not far removed in this respect from the MSA and the LAS, but quite distinct from that of the kośakāra. It is still too early, however, to draw firm conclusions on this basis.

\section{Verse formulas in TSN 10-21}

The use of the verb khya is not the only feature of the TSN that leads me to question its association with Vasubandhu, the author of the $\mathrm{ADhK}(\mathrm{Bh})$. Another notable aspect of the text is the often formulaic patterning of its verses, the author ringing the changes on a series of specified topics, including existence and non-existence, unicity and duality, affliction and purification. ${ }^{57}$ Throughout this section of the work, the verses have the appearance of having been generated through an exercise of substitution. Verses 11-13, on the "characteristic of being-cum-nonbeing" (sadasallakșaṇa) may serve as an example:

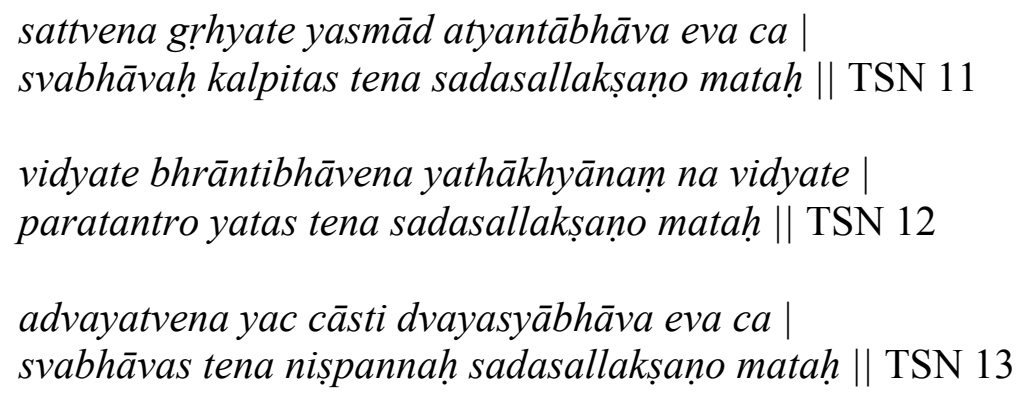

Because it is grasped as what is and yet is entirely without being, the constructed nature is thought to have the characteristic of being-cum-nonbeing. (11)

It is found [i.e. "exists"'] owing to the occurrence of error, but not found as it appears; hence, the heteronomous is thought to have the characteristic of being-cumnonbeing. (12)

That which exists as nonduality, and is duality's nonbeing as well, is the consummate nature, which is thus thought to have the characteristic of being-cum-nonbeing.

In this part of the work, it is possible that the TSN was inspired primarily by the MAV, in which the topics of existence and non-existence, and affliction and purification are prominent. For instance, in MAV I.2 we read:

satvād asatvāt satvāe ca madhyamā pratipac ca sā. 
"That is the middle path, owing to being [= the conceptualization of what is unreal], nonbeing [= duality], and being [= emptiness]."

Commenting on this verse, the MAVBh tells us that "in this way the characteristic of being and the characteristic of nonbeing in connection with the conceptualization of the unreal have been made known" (evam abhütaparikalpasya sallakșaṇam asallakșaṇam ca khyāpayitvā). ${ }^{58}$

Returning now to the formulaic aspect of the verses throughout this part of the TSN, I do not know of any other point at which the kośakāra adopts this particular authorial device, and, though others may assess this differently, to me it just doesn't feel like Vasubandhu. ${ }^{59}$ For in contrast with the elegance and precision of reason that characterize the kośakāra's established works, this part of the TSN appears to have been generated almost as if by a mechanical substitution procedure, with sometimes careless results, as may be seen in the tautological formulation we find above in verse 13: "That which exists as nonduality, and is duality's nonbeing as well ..."60 Another example of the carelessness to which I refer in this section is evident in TSN 14-16, on unicity and duality. Here we read:

dvaividhyāt kalpitārthasya tadasattvaikabhāvatặ|
svabhāvaḥ kalpito bālair dvayaikatvātmako matạ || TSN 14

prakhyānād dvayabhāvena bhrāntimātraikabhāvatah svabhāvah paratantrākhyo dvayaikatvātmako matah || TSN 15

dvayabhāvasvabhāvatvād advayaikasvabhāvatah svabhāvah pariniṣpanno dvayaikatvātmako matah || TSN 16

Owing to the dimorphism of the constructed object and to the oneness of its nonexistence, the nature constructed by the childish is considered to be duality and unicity in essence. (14)

Owing to its dualistic appearance and its being one as error alone, the nature called "heteronomous" is considered to be duality and unicity in essence. (15)

Owing to its dual nature and because its nature is one in nonduality, the consummate nature is considered to be duality and unicity in essence. (16)

Each of the three natures is attributed in turn with the apparently contradictory properties of unicity and multiplicity. In respect to the first two, parikalpita and paratantra, there is no actual contradiction at stake here, because the predicates in question, although applied to the same subjects, are not so applied with the same determinations: the constructed nature is two in respect to the apparent subject-object dichotomy, but just one insofar as that dichotomy is unreal; and the dependent nature, in practically the same terms, is dual owing to subject-object appearance, and one because this is a single error. A fish is many in respect to its scales, but just one in virtue of its fishiness! The treatment of the third nature, parinispanna, is particularly problematic because, following the reading in the manuscript"Owing to its dual nature and because its nature is one in nonduality" - it seems to be the assertion of a flat contradiction, and, though the emendation proposed by Mukhopadyaya avoids this (see n. 60), we are then left with a simple tautology. Could this possibly be the 
work of the same philosopher who wielded the argument of the one-and-the-many with such devastating effect in his refutation of physicalist theories of matter in the Vimśik $\bar{a} ?^{61}$ What he saw so clearly there - that paradox is generated when the subject in question must be one and many in respect to a single quality or feature-is completely lost in the present text, which seems puzzlingly imprecise in its deployment of the one-and-the-many. There is a very great gulf separating the logical acuity of the kośakāra from the mystico-philosophical approximations we find in this part of the TSN. ${ }^{62}$

\section{Discrepancies with the Triṃśikā}

Besides the concerns raised in the foregoing sections, the TSN may also be considered in its relation to the teaching of the three natures as set forth in the most influential work Vasubandhu wrote treating of this topic, the Trmis. Given the demonstrable authority of that work within subsequent Buddhist thought among the kośakāra's Yogācāra writings, inconsistencies between it and the TSN would tend to support the conclusion that they were not likely composed by the same figure. ${ }^{63}$

Daniel McNamara, in a recent paper, has argued that the "progressive" model of the three natures affirmed in some passages in the TSN is quite distinct from the "pivotal" model elaborated in Vasubandhu's Trmś. ${ }^{64}$ His observations about this are inspired by Sponberg's insightful and influential typology of approaches to the three natures in Yogācāra literature, wherein the pivotal model is the model employed in the Mahāyanasamgraha, the great work of Asanga in which we find perhaps the most systematic expression of early Yogācāra thought. ${ }^{65}$ According to this model, the heteronomous nature operates as a sort of ontological pivot, for it is the locus of conceptual construction and at the same time it is that which, being essentially nondual, is none other than the consummate nature. The "progressive" model, however, treats the constructed nature as altogether vitiated by error, the heteronomous nature as so vitiated insofar as it is the basis of the constructed nature, and the consummate nature to be the pure locus of true reality. On McNamara's reading, these two models are ontologically and soteriologically incompatible with one another.

Now, I believe that McNamara is certainly correct in emphasizing the commitment of the Trmśs to the pivotal model:

$$
\begin{aligned}
& \text { yena yena vikalpena yad yad vastu vikalpyate | } \\
& \text { parikalpita evāsau svabhāvo na sa vidyate || Trṃś } 20 \\
& \text { paratantrasvabhāvas tu vikalpah pratyayodbhavah | } \\
& \text { niṣpannas tasya pūrvena sadā rahitatā tu yā || Trṃś } 21 \\
& \text { ata eva sa naivānyo nānanyah paratantratah } \\
& \text { anityatādivad vācyo nādrșțe 'smin sa dṛ́syate || Trmśs } 22
\end{aligned}
$$

Whatever thing is constructed by whatever conceptual activity is the conceptually constructed nature; [that thing] is not found [to exist]. (Trmís 20)

The heteronomous nature is conceptualization as causally originated. And the consummate is its [the heteronomous nature's] eternal deprivation of the aforementioned [conceptual construction]. (Trmś 21) 
Hence it is neither different nor undifferentiated from the heteronomous, but is said to be like impermanence and such [properties that characterize conditioned entities]. [In like manner,] it [the consummate] is not seen when this [the heteronomous] is not seen. (Trṃś 22)

In other words, the heteronomous nature is treated here as none other than the common ground of conceptual construction, through which a false subject-object dichotomy is projected, and of the consummate nature, which is nothing other than the absence, in reality, of the dichotomy that is falsely projected.

Moreover, the passages cited by McNamara in proposing that the TSN supports the progressive model appear prima facie to confirm just that:

arthatattvaprativedhe yugapal lakșanatrayam | parij̄ña ca prahānam ca prāptiś ceșțā yathākramam || TSN 31

parijñānupalambho 'tra hānir akhyānam ișyate | upalambhānimagnas tu prāptiḥ sākșātkriyāpi sā || TSN 32

On penetrating true reality, simultaneously the three modes are held to be thoroughly known, abandoned, and acquired in that order. (31)

Here, "thoroughly knowing" [conceptual construction] is held to be nonobjectification, "abandoning" [of the heteronomous] is non-appearance, and "acquisition" [of the consummate] is the absence of obsession with objects, ${ }^{66}$ whereby it is made manifest. (32)

The progressive model, as we find it articulated here, is presented in terms that closely approximate those of the of the $\operatorname{MSA}(\mathrm{Bh})$, which tells us, for example, that:

MSABh ad 11.13: satatam dvayena rahitam tatvam parikalpitah svabhāvo grāhyagrāhakalakṣaṇenātyantam asatvāt | bhrānteh samniśrayah paratantras tena tatparikalpanāt | anabhilāpyam aprapañcātmakam ca pariniṣpannah svabhāvah | tatra prathamam tatvam parijñeyam dvitīyam praheyam tṛtīyam viśodhyam cāgantukamalād ...

The conceptually constructed nature is that reality which is always devoid of duality, for it is entirely without the characteristics of apprehended object and apprehending subject. The heteronomous is the ground of error, for owing to it there is the conceptual construction of that [duality]. The consummate nature is ineffable and naturally free from conceptual proliferation. There, the first reality is to be thoroughly known, the second to be rejected, and the third to be purified of adventitious taints ...

Nevertheless, I think it possible to read the TSN as an attempt to reconcile the pivotal and progressive models, which may weaken somewhat the force of this argument. For the two approaches are not quite incompatible. The pivotal model may be taken to be primarily ontological in its concerns; it tells us what there is and how things are. The progressive model, on the other hand, is above all about soteriology; it tells us how an adept on the path comes to engage with the three natures. In particular, as the use of the adverb yugapad, 
"simultaneously, all at once," in TSN 32 suggests, the progressive model is perhaps being read here as not requiring a literal progression at all. This is an important point in our understanding of the TSN, to which we shall have occasion to return shortly. If I am more or less correct about it, the break between the Trmś and the TSN is probably more radical than the contrast of pivotal and progressive models alone suggests. The TSN may be read as seeking to reconcile the two, but at the cost of overturning an essential dimension of the classical Yogācāra vision of the Buddhist path.

At the same time, it must be stressed that, to the extent that it incorporates the pivotal model, the TSN does not at all espouse it as it is known from the Mahāyanasamgraha and the Trmś. It argues (TSN 17-20), rather, for the identity of the three natures, the constructed and the heteronomous being considered therein as inseparable (abhinna) from the consummate nature in virtue of their nonduality. This seems a remarkable difference from the Trmś and other articulations of the pivotal model, where the fulcrum is always seen as the heteronomous.

Two additional features of the TSN further accentuate, in my view, the doctrinal discrepancies between that text and the other Yogācāra works of the Vasubandhu corpus. Surprisingly, given its concern to explicitly ring the changes on the teaching of the three natures, it offers no clear remarks on the three natures' nihsvabhāvatā, their insubstantiality. Although this topic is perhaps in some sense implied by the TSN's exposition of the inseparability of the consummate nature from the other two, this is not similar to the approach taken in the Trmś, where Vasubandhu emphasizes the distinctly different types of insubstantiality corresponding to each of the three natures. ${ }^{67}$ The author of the TSN, however, with markedly less subtlety, treats the inseparability of three natures as a function of their common nonduality.

Second, as suggested earlier, the Trmś and the TSN belong to quite different soteriological universes, something I find impossible to reconcile with Vasubandhu as I know him. For whereas the Trmś clearly entails a commitment to a classical Yogācāra view of buddhahood achieved through áśrayaparāvrtti, the "inversion of the ground" whereby the eight mundane groups of consciousness are transfigured so as to emerge as the gnosis and embodied structure of buddhahood, ${ }^{68}$ the TSN affirms that it is the knowledge of the three natures as they are that is itself liberating "without effort":

\section{viruddhadhīkāranatvād buddhyā vaiyarthyadarśanāt | jūānatrayānuvṛtteś ca mokṣāpattir ayatnatah || TSN 35}

By reason of opposing ideas, owing to the intellectual vision of objectlessness, and due to the pursuit of threefold gnosis, liberation is attained without effort. (35)

The interpretation of this verse in full detail remains elusive. ${ }^{69}$ What must be stressed in our present context, however, is its unambiguous conclusion: "liberation is attained without effort." Recall now the author's earlier insistence on the simultaneity of knowledge, abandonment, and attainment, when the reality of the three natures is known.

Vasubandhu the kośakāra, I believe it is safe to say, was surely a determined gradualist; the gesture in favor of effortless enlightenment in the TSN seems not to emanate from his voice at all. Furthermore, turning to the larger Vasubandhu corpus, both the MSABh and the MAVBh frankly declare views advocating "enlightenment without effort" anathema: 
MSABh ad 18.103: yadi cātmadarśanena mokșa ityasau deśyeta | evamsati syāt ayatnamokṣah sarveșām.

If it were taught that the vision of self is liberation, then, that being the case, there would be liberation without effort for all.

MAVBh ad 1.21 yadi dharmāṇām śūnyatā āgantukair upakleśair anutpanne 'pi pratipakșe na saṃkliștā bhavet saṃkleśābhāvād ayatnata eva muktāh sarvasatvāa bhaveyuh.

If the emptiness of phenomena were not afflicted by the desultory affects, even without the occurrence of the antidote [to such affects], then all beings would be liberated indeed without effort.

It is of course true that the word ayatna, "without effort," is sometimes used to mean not literally "effortless" but something closer to "easy, without difficulty." ${ }^{\text {"70 }}$ However, the explicit condemnation of views entailing "effortless liberation" that we find in two of the most influential Yogācāra works of the Vasubandhu corpus inclines me to hold that the more casual use of the term cannot be at issue in the present instance. My reading of this is consistent, moreover, with the concept of simultaneous realization we have seen in TSN 31 .

\section{Summing Up}

The facts that I have surveyed do not, in my view, quite succeed in demonstrating the incorrigibility of my original "a-ha!" moment: "this could not possibly be by Vasubandhu." However, they do provide reasons for doubt, on philosophical, philological, and historical grounds. Taken together, the force of problematic issues raised in not one or two but all three of these areas suggests to me that the attribution of the TSN to Vasubandhu can no longer be accepted.

Among the doctrinal and philosophical arguments, those concerning the "pivotal" vs. "progressive" models of the three natures seem of uncertain force, particularly if we see the TSN as seeking to reconcile the two models. The TSN's silence on nihsvabhāvatā is puzzling, as is its apparent undermining of the progressive model through its recourse to simultaneous realization. The broad-brush treatment of the question of the one-and the-many in verses 1416, as we have seen, notably contrasts with the kośakära's crisp logic in formulating this a version of this conundrum elsewhere. And the TSN's apparent gesture to gnosticism, its espousal of "effortless liberation," seems entirely incompatible with the thinking represented elsewhere in the Vasubandhu corpus. Given the opprobrium attached to the notion of "effortless liberation" in classical Yogācāra doctrine, I do not think it plausible to regard the TSN's employment of it to have been merely an innocent euphemism.

The philological arguments pose problems for the ascription of authorship too. The systematic use of $k h y \bar{a}$ and its derivatives in meanings relating to "appearance, manifestation," is unlikely to have been the usage of Vasubandhu the kośakāra. And the rigidly parallel formulations that characterize the TSN in verses 10-21 seem also out of character for him. Although we know that the author of the MSABh, in accord with the root text of the MSA, used khya in a manner resembling that of the TSN, we also know that this author, as well as 
the author of the MAVBh, whether or not they were one and the same person, explicitly condemned views entailing "effortless liberation," a consideration that seems to exclude his/their having had any role in the TSN's composition.

Finally, the historical case, though perhaps not seen in its full force when taken alone, assumes new weight when considered in relation to the foregoing matters. Is it really plausible to hold that a text of just a single palm leaf or two in length, out of harmony with Vasubandhu's other known writings and to which there is no reference or allusion throughout the Yogācāra corpus, or anywhere else in first millennium Indian philosophical literature so far as we know, reappeared somewhere in North India after having vanished seven centuries before? Try as I might, I cannot easily envision such a scenario. Although India offers numerous examples of genuinely old works found only in late manuscript copies - indeed this is true of all of Vasubandhu's writings for which we have Sanskrit texts-we are typically able to construct, through references culled from a variety of sources, as well as through philological details, a coherent story underwriting the authenticity of the writings in question. Not so in the present case, however. Add to this the silence of the Chinese record in respect to the TSN-above all the silence of Xuanzang, one of the greatest authorities on Yogācāra, Vasubandhu, and the three natures doctrine throughout the entire history of Buddhist learning - and the one thing that begins to seem truly odd in this story is that the TSN has been so widely taken by contemporary scholars to be an authority at all.

But if the TSN's credentials for inclusion among the core writings of Vasubandhu are doubtful, how are we to class it? Is to be counted among the works that nevertheless emanated from Vasubandhu's circle, so to speak, or is it pseudepigraphical? And if the latter, when and under what circumstances may we assume it to have been created?

The option of rejecting the kośakära's authorship but nonetheless admitting the TSN to be part of the larger Vasubandhu corpus initially seemed to me to be an attractive solution, for this does succeed in addressing several of the philological and doctrinal concerns. The use of the verb $k h y \bar{a}$, for example, appears sufficiently close to what we find in the MSA and the LAS so that the composition of the TSN by someone familiar with those texts can be plausibly imagined, and, as we have seen, the TSN exhibits parallels with parts of the $\mathrm{MAV}(\mathrm{Bh})$ as well. Perhaps, then, the problems raised in this article do not succeed in excluding the possibility that the TSN is a genuinely old Yogācāra text. Perhaps it was written by someone close to Vasubandhu (or by one of the Vasubandhus besides the kośakāra).

However, if an original, short work by Vasubandhu, entirely unknown to the tradition, could not likely have disappeared and then been recovered after a span of some seven hundred years, is there any better reason to suppose that a product of the broader "Vasubandhu circle" might have done so? If we have an equally compelling or better explanation as to how the text might have arisen as a late pseudepigraphon, then why not opt for it, by reason of the inference to the best explanation? We must now consider, therefore, whether such an explanation is available to us.

Setting aside for the moment the question of "effortless enlightenment," I have argued above, on philological and doctrinal grounds, that the TSN seems most closely related, among Yogācāra works, to the MSA, the MAV, and the LAS. In fact, I believe that the TSN should in fact be regarded, at least in its basic elements, as a sort of digest of the three natures doctrine as it is elaborated in these texts. If we return to my observations above, concerning 
the use of the verb khya in both the TSN and the MSA, together with its association in both with the doctrine of the three natures, we may find some interest too in the fact that the TSN, by adopting the diction of the progressive model of the three natures, accords more closely with the standpoint of the MSA than it does with that of the Trmś. This, taken together with the knowledge that there was revived interest in Yogācāra teaching in very late Indian Buddhism, as well as numbers of brief doctrinal digests in verse written during this period, ${ }^{71}$ suggests to me that the TSN is plausibly a product of this late Indian Buddhist milieu. Indeed, one such doctrinal digest, in the field of Madhyamaka, is the *Madhyamakaprajñ $\bar{a} v a t \bar{a} r a$ of the Kashmiri scholar Candrakīrti, the translator of one of the Tibetan versions of the TSN. Is there also perhaps some significance in the fact that this work, too, takes up the example of the illusory elephant? ${ }^{72}$

Earlier I stated that the opposition of Vasubandhu and Nāgārjuna as putative authors of the TSN was perhaps not to be taken as a simple binary. An evident tertium quid is of course the possibility that the work appeared anonymously and was subsequently attributed to well-known authors according to the fancies of the scribes. Moreover, as numerous examples tell us, later Indian Buddhists were fond of recycling the names of earlier masters: Nāgārjuna, Āryadeva, Candrakīrti, Dharmakīrti, Śāntarakșita and Kamalaśīla were all subject to one or more recurrences. ${ }^{73}$ In the case of the TSN, I would suggest that it came into circulation either through the Kashmiri Candrakīti or persons close to him, or through persons connected with the tradition of Ratnākaraśānti in the northeast of India, that is to say, the tradition with which the scholar Śantibhadra was most closely associated. ${ }^{74}$ That these were no so distant from one another as reference to Kashmir and Bihar might otherwise suggest is established by the knowledge that the Tibetan translator 'Gos Khug-pa-lhas-btsas collaborated with both of these figures and by the recent discovery that writings of Ratnākaraśānti became available in Kashmir soon after their composition during roughly the period with which we are concerned. ${ }^{75}$ In short, my view is that the TSN was likely produced by votaries of tantric Buddhism during the eleventh century and came to be attributed to Vasubandhu only after it had entered into circulation. Such an hypothesis would cohere well with the affirmation of "effortless liberation" in the TSN-one point that I cannot reconcile at all with early Yogācāra teaching-for precisely such a view was current in Buddhist tantric circles of the eleventh century, as well as among certain Śaivas of Kashmir. ${ }^{76}$

If an interpretation of the evidence along the lines proposed here is credible, what does it say in regard to our use of the TSN, our treatment of it not only as a genuine work of Vasubandhu but indeed as one of his key Yogācāra contributions? At the outset, I would suggest that we need to be more conscious of the manner in which we, as contemporary scholars of Buddhism, are engaged in our own acts of canon-formation, and that our vision of the history of Buddhist philosophy as of the thinkers who contributed to that history is constrained by the canon that we ourselves have formed. We must recall that historical research is not a matter of gaining privileged access to a now vanished past, but, as the great philosopher and practicing historian R. G. Collingwood reminds us, "history is a special form of thought." 77 Just how that thinking unfolds will depend in part on our own capacities of imagination and reason, but also on the decisions we take with respect to the value of this or that authority. For myself, I do not think that excluding the TSN from among those works that I accept as representative of Vasubandhu and/or of early Yogācāra will significantly alter my vision of either. In this respect, my proposal to consider the text suspect amounts to no more than a relatively minor revision, except insomuch as the TSN has come to enjoy an exaggerated importance in some trends within recent Yogācāra scholarship, particularly in connection with the much-discussed question of whether or to what degree Yogācāra and 
Madhyamaka are opposed. ${ }^{78}$ My argument implies that the TSN should have no place at all in our thinking about Vasubandhu's position in that debate. However, if the assessment of the TSN I am proposing here is viable, the importance of the TSN is to be found in what it may tell us of intellectual activity within the very late Indian Buddhist tradition, when, as we know from other examples, efforts were made to resume key elements of the Buddhist philosophical legacy with clarity and concision, with ideas driven by the interests of tantric circles sometimes in view.

\section{Notes}

${ }^{1}$ Gold (2015): 1. I wish to thank Jonathan Gold, who kindly invited me to present an earlier version of this work to the Columbia Society for Comparative Philosophy in February 2017, and Jay Garfield, whose comments on that occasion helped me to think through the task of reworking it for publication. I am also very grateful to Shayne Clarke, Paul Hackett, Seishi Karashima, Kei Kataoka, Birgit Kellner, Isabelle Ratié, David Reigle, ${ }^{2}$ Notably by Schmithausen (1987), part II, p. 263, who says of it that "the authorship ... may at any rate need reconsideration." Cf. also his remarks in (2014): 27, n. 53. Others have also found it to be unusual; Kochumuttom, for example, who included it in his translated selection of Vasubandhu's texts, nevertheless seems to have hesitated and wrote (1982): xix, "Its style might appear a little different from the other works of Vasubandhu. If that can be ignored, one would reasonably say that this text forms an integral part of his independent works ...." And Wood (1991): 31 is quite circumspect, saying that it "may not have been written by Vasubandhu."

${ }^{3}$ As I was completing work on this article, I became aware of Sugawara (1996), an article in Japanese and so unfortunately beyond my linguistic abilities. In the bibliography through which I learned of it, Kragh (2013): 280, it was given the English title "Text Critical Problems in Vasubandhu's Trisvabhāvanirdeśa," but the German title found in the original publication, and given in the references to the present article, made it clear that Sugawara's thinking was not far from my own. Following the romanized Sanskrit that peppers his article, it is evident that he lays stress, as I do as well, on the pecular use of the verb khya in the text. Besides this, however, we may have chosen somewhat different points of emphasis.

${ }^{4}$ Yamaguchi (1931). Yamaguchi (1972), vol. 1, pp. 119-162, reproduces this edition, with notes recording variants from La Vallée Poussin (1933) and Mukhopadhyaya (1939), as well as the addition of the second Tibetan translation that had been omitted from his original article in 1931.

${ }^{5}$ La Vallée Poussin (1933).

${ }^{6}$ Mukhopadhyaya (1939). In my remarks on parallels between the TSN and other texts in what follows, I have independently selected the passages I discuss, though inevitably overlapping with Mukhopadhyaya's selection at some points. It may be noted, too, that the latter lays considerable emphasis on apparent parallels in the LAS. Though interesting, the implications of parallels with the LAS remain uncertain, as it is now generally accepted that the LAS as we know it must post-date Vasubandhu.

${ }^{7}$ As will be seen in what follows, I have referred to the facsimile of the manuscript to verify readings that seemed problematic. The most significant modification that I propose is in TSN 32, as discussed in n. 66 below. ${ }^{8}$ Mimaki et al. (1989): plate 3, folio 3a, line 4.

9 'Gos Khug-pa Lhas-btsas is primarily known for his role in the transmission to Tibet of the Guhyasamājatantra according to the "Ārya" tradition ascribed to Nāgārjuna. His career is summarized in the Blue Annals, Roerich (1949): 360-364. His collaborator, Śāntibhadra of Rājagṛha, assisted a number of prominent Tibetan translators of the mid eleventh century, including, besides 'Gos, Nag-tsho Tshul-khrimsrgyal-ba (1011-1064), who had been entrusted with the mission of inviting Atiśa from India to Tibet. To judge from the list of translations in which he participated, Śāntibhadra played an essential role in transmitting to Tibet the works of Ratnākaraśānti, whose Yogācāra-infused approach to Tantric interpretation seems particularly suggestive in our present context. In the Peking edition of the Tanjur, Sāntibhadra is credited with participation in the translation of twenty-two texts on both tantric and exoteric subjects, of which eight (nos. 2319, 2714, 3301, 5199, 5459, 5577, 5586, 5756) are by Ratnākaraśānti.

${ }^{10}$ I have prepared, for publication in the near future, a short article containing an edition and translation of the * Madhyamakaprajñāvatāra (Peking 5264).

${ }^{11}$ This title surely refers to TSN 24-25: dvayābhāvātmakah pūrvamparatantrah praviśyate / tatah praviśyate tatra kalpamātram asaddvayam // TSN 24 // tato dvayābhāvabhāvo nișpanno 'tra praviśyate /tathā hy asāv eva tadā astināstīti cocyate // TSN 25 // "One first penetrates the heteronomous, whose nature is the absence of duality. Then and there, one penetrates mere construction, wherein duality does not exist. (24) Here, then, one 
penetrates the absolute, whose being is duality's nonbeing. For so it is that it can then be spoken of in terms of 'is and is not.' (25)"

${ }^{12}$ These two verses, inserted after verse 26, are puzzling and stumped La Vallée Poussin, who nevertheless attempted a Sanskrit reconstitution of them. I am also uncertain about exactly how they are to be understood, though they clearly concern ways of analyzing or subdividing the three natures, in some respects echoing what is found earlier in verse 10. This is all the more strange because the "Nāgārjuna" version otherwise is often clearer in Tibetan than is the "Vasubandhu" text (though there are some exceptions to this), and in many cases it corresponds more closely to the extant Sanskrit as well.

${ }^{13}$ As Buescher (2013) has carefully documented, La Vallée Poussin was troubled by problems associated with the name Vasubandhu as early as 1919. His hasty affirmation of Vasubandhu's authorship in the present case is therefore something of a mystery.

${ }^{14}$ Anacker (2005 [1984]): 289; Garfield (2015): 187.

${ }^{15}$ Garfield, ibidem, refers to the authority of "the biography of Vasubandhu" on this point, without further specification, but none of the traditional biographies known to me lends any support to this assertion.

${ }^{16}$ As this has become a conventional and convenient English rendering of trisvabhāva, I continue to use it here for simplicity's sake. However, I believe that it would be more appropriately nuanced to adopt an expression such as "three modes of being" in this context. Where lakșana is used instead of svabhāva, however, I do use "mode," though it would probably be more precise to speak of the "defining characteristics" of the three categories defined.

${ }^{17}$ See, in particular, Trimiśikā (Trmś), vv. 20-25, to which we shall return below.

${ }^{18}$ Anacker (2005 [1984]), Brunnhölzl (2007), Garfield (1997) [reprt. in Garfield (2002), and in Edelglass and Garfield (2009)], Gold (2015), Kochumuttom (1982), Tola and Dragonetti (1983, reprt. in 2004), and Wood (1991). Among other languages, recent translations in modern Chinese (Han 1998, Jin 2008, Liu 1986), French (Cornu [2008]), Spanish (Tola and Dragonetti [1989]), and Hindi (Chogḍub and Tripāthī [1972]) have also appeared. Yamaguchi ([1931], [(1972): vol. 1, pp. 119-162]) includes a Japanese translation, as does Nagao (1976).

${ }^{19}$ Besides works already mentioned, one may note Boquist (1993): 116-132, Carpenter (2014): 186-189, Garfield in Garfield and Westerhoff (2015): 252-273, Lusthaus (2002): passim. There appears to be a peculiarly close relation between the discussions of the TSN found in Carpenter 2014 and Garfield 2015, e.g., in that both mention a "biography" of Vasubandhu that supposedly speaks of the TSN as that thinker's "last work." But it is not clear to me what the common source for this may have been. Lusthaus, it may be added, though referring to the TSN on occasion in his 2002 publication, no longer considers it to be an authentic text by Vasubandhu. I am grateful to him for clarifying his current view of the TSN, which closely accords with my own (correspondence 26 May 2017).

${ }^{20}$ Boquist (1993): 116 mentions two manuscripts of the TSN, citing Nakamura (1987) and Powers (1991) as sources for this information. Neither in fact asserts there to have been two manuscripts and it is most likely that Boquist is actually referring to Tola and Dragonetti (1983): 225-226. However, I have not located evidence for the existence of a second manuscript and believe that this may have been a misunderstanding on their part. It is clear that more than one copy of the manuscript - now archived as No. 5-6462 in the National Archives of Nepal - was prepared after it was discovered in the 1920s. Mukhopadhyaya (1939): vi explicitly states that the text he received from Tucci was such a copy. The variants in the Sanskrit text carefully enumerated by Tola and Dragonetti in comparison with the edition first published in Yamaguchi (1931) were certainly due to various "corrections" and mistakes introduced by the copyists, not to the existence of a second original witness. (That Yamaguchi was working from a hand-copy and not from photographic plates of the original manuscript is demonstrated by the copyist's annotation-nevārākșaralikhitā prācinatā [la]patrodgatā, "drawn from an old palm-leaf manuscript written in Newari script"-included in his transcription of the text.) On the other hand, the two Tibetan translations, despite their broad agreement, do appear to reflect some genuine variants in the text itself above and beyond the differing attributions of authorship and the addition of two verses in the "Nāgārjuna" version.

${ }^{21}$ Jaini (1958) suggested that a reference in the Abhidharmadīpa to Vasubandhu, the kośakāra, as upholding the trisvabhāva doctrine may be an allusion to the TSN. But, as no further information about the doctrine in question is to be found in the Abhidharmadipa, besides this brief mention, and as we know that Vasubandhu in any case discusses trisvabhāva elsewhere, this is unwarranted.

${ }^{22}$ The fact that neither Paramārtha (499-569), nor Xuanzang (602-664) demonstrates any knowledge of the TSN is particularly worrisome. Considering above all the latter's special concern to collect and document the commentarial tradition of the Trmś, it beggars the imagination to suppose that he did not encounter the TSN in some form, were it really a well-regarded work on an important Yogācāra theory authored by Vasubandhu. Is it at all plausible that he spent years at Nālandā devoting particular attention to the writings on the Trmś by 
Dharmapāla, Sthiramati, Nanda, Citrabhānu, Guṇamati, Jinamitra, Jñānacandra, Bandhuśrī, Śuddhacandra and Jinaputra and yet never heard a whisper, much less saw a citation, of the TSN, if this were indeed Vasubandhu's definitive statement on the three natures, as some now suppose it to be?

${ }^{23}$ At least nineteen works attributed to Vasubandhu were available in Tibetan versions by the early ninth century. Refer to Herrmann-Pfandt (2007).

${ }^{24}$ See, for instance, Bu-ston's influential version in Obermiller (1931), Part II, pp. 142-147; for Tāranātha's, refer to Chattopadhyaya (1981): 167-175.

${ }^{25} \mathrm{Bu}$-ston (1988): 239 records the version attributed to Vasubandhu, but makes no mention of the Nāgārjuna text. The Tanjur catalogues attributed to the third Karma-pa hierarch Rang-byung-rdo-rje (1284-1339), however, list both translations, as does the mid-fourteenth-century catalogue of the Ngam-ring Tanjur manuscript: Loyag-bkra-shis, vol. 4, pp. 556 and 576; Phyogs-las-rnam-rgyal (2010): 130 and 150

${ }^{26}$ Rig-pa'i-ral-gri (2009): 422.7: slob dpon dbyig gnyen gyis rang bzhin gsum bstan pa las/ rang bzhin gsum po bstan rnams kyi// zab mo yi ni shes par 'dod// = TSN 1cd.

433.3-4: rang bzhin gsum bstan pa las kyang/ gnyis po dmigs su med pa na// chos kyi dbyings la dmigs par 'gyur//= TSN 37ab.

Interestingly, Bcom-ldan-ral-gri seems not to mention either of the two Tibetan versions of the TSN in his "survey of Buddhist literature," the Bstan pa rgyas pa rgyan gyi nyi 'od, a point that may shed some light on the question posed by the editors of that text in regard to whether or not the author was referring to an actual collection of texts at his disposal or merely to earlier catalogues: Schaeffer and van der Kuijp (2009): 60.

${ }^{27}$ Tāranātha (2004): 34: rang bzhin gsum la 'jug pa'i sgrub pa las kyang/ kun btags dang ni gzhan gyi dbang// nyon mongs mtshan nyid shes par bya// rnam par byang ba'i rang bzhin ni// yongs su grub par 'dod pa yin//= TSN 17.

${ }^{28}$ Chattopadhyaya (1981): 162, notes the discrepancy in the assignment of the TSN to Asanga here.

${ }^{29}$ As the history and development of the debate have been thoroughly discussed in the works to which I refer herein, I trust that my readers will not require a new recapitulation of all this here. Buescher (2013) and Gold (2015) detail the state of play from opposing perspectives and, taken together, very adequately map the terrain. ${ }^{30}$ Skilling (2000) is particularly compelling on this issue. Refer to Buescher (2013) for subsequent refinements in the determination of the relations among the works of the kośakāra.

${ }^{31}$ This last work, of great importance for the reception of Vasubandhu and the Yogācāra tradition in East Asia, has been but poorly studied in Euro-American Buddhology. Rahder (1926) remains the major contribution to date.

${ }^{32}$ In addition to cross-references among the works of the kośakāra, as demonstrated by Skilling, Schmithausen (1987), part II, p. 263, suggests that the concept of santāna-parināma-viśeșa may be a distinguishing feature of that thinker's work. Cf. the supporting comments of Buescher (2013): 385-387.

${ }^{33}$ Buescher (2013). Although I do not believe that he used the expression "bhāsyakāra," Schmithausen's division of the Vasubandhu corpus largely anticipates Buescher's proposals.

${ }^{34}$ Gold (2015) offers a particularly sustained and spirited defense of single authorship. However, I do not think that he has fully assessed the import of the key evidence adduced by Buescher (2013), including the critical reference by the author of the ADhKBh to an argument that can be indeed found in the MSABh, together with a comment by Yaśomitra explicitly naming the author of the latter argument as the "elder Vasubandhu." It seems to me very difficult to evade Buescher's point here. Note, too, that Horiuchi (2009) lends some support to Buescher's thesis by demonstrating that the kośakāra was indeed familiar with the MSA, though Horiuchi's own conclusion, that this suggests that the kośakära may have been the author of the MSABh, does not seem to me to follow.

${ }^{35}$ Skilling (2000): 312: "Sthiramati gives a direct citation in several lines of the view of this "earlier Vasubandhu', not given by Yaśomitra. The references deal with points of interpretation of the Abhidharma. All that can be said is that there was indeed an earlier Vasubandhu, who worked within the (Mūla)Sarvāstivādin or Vaibhāṣika tradition."

${ }^{36}$ Some caution is required here, as Sthiramati may have followed Vasubandhu by somewhat more than a century and, as Frauwallner (1951) famously argued in respect to traditions concerning the number of Vasubandhus, over such a period of time human memory tends to be frail. Against this, however, it should be stressed that institutional memory is generally far more secure than feeble individual memory and, during the period with which we are here concerned, Buddhist institutions in India were flourishing. Under such circumstances, it seems less plausible that mere human fraility can sufficiently account for the conflation of the kośakāra and the bhāṣyakāra.

${ }^{37}$ Kramer (2016). In fact, Kramer's reservations regarding the common authorship of the Sthiramati commentaries appear to me to point, in regard to that figure, in the direction of a hypothesis similar to that sketched in the paragraphs that follow with respect to Vasubandhu. 
${ }^{38}$ In fact, this question might be resolved if we were prepared to take seriously Paramārtha's tale of Vasubandhu's having been one of three brothers all named Vasubandhu, of whom Asanga was the eldest. For then the senior Vasubandhu might be identified as the bhāsyakāra and turn out also in fact to have been Asanga! Gold (2016): 11 proposes something similar, as Wayman did earlier (see Buescher 2013, n. 10). Unfortunately, the ready acceptance of the hagiographical tradition surely is not a genuine option.

${ }^{39}$ Naanamoli (1980): 235. I thank Steven Collins for calling my attention to this comment.

${ }^{40}$ Sakuma (2013): 337.

${ }^{41}$ Twice each in TSN 2, 3, and 4; once each in TSN 12, 20, 21, 27, 29 and 32. Additionally, in TSN 15 pra-khya occurs once with the same meaning. In TSN 20 we find one instance of $\bar{a}-k h y \bar{a}$ in the sense of "to call, to name." The peculiar use of khya in the TSN has been noted by others, but not always with the same assessment.

Nakamura (1987): 271, n. 20, for instance, remarks: "In this treatise a concept khyâti is used which means the 'appearance of a figure or a concept' ... The khyātr [in TSN 3] is the subject which turns from infatuation to enlightenment, from samsāra to Buddha." But insofar as this may be taken to imply the hypostasis of the subject-agent, it departs, in my view, from the purport of the TSN, which remains always within the ambit of anātmavāda.

${ }^{42}$ Böhtlingk and Roth (1855): vol. 2, p. 620.

${ }^{43}$ Monier-Williams (1956 [1899]): 341.

${ }^{44}$ The noun khyāti does occur at Amarakośa 3.2.9, but in the sense of "fame, notoriety."

${ }^{45}$ Bhațāāārya (1873): 2479.

${ }^{46}$ By contrast, in Pātañjalayogasūtra 2.26, the term is used to refer to knowledge that correctly distinguishes puruṣa from buddhi.

${ }^{47}$ Summarized in Jhalakīkar (1978 [1928]): 255-257. A broad philosophical survey of the question may be found in Rao (1998). For detailed consideration of khyāti in Advaita-Vedānta, see, in particular, Schmithausen (1965).

${ }^{48}$ Kumar (1938): 60-66. Note, too, the recently published treatment of the topic in the work of the Nyāya philosopher Bhatța Jayanta: Kataoka (2017).

${ }^{49}$ In order to estimate the number of instances of $k h y \bar{a}$ and its derivatives in each text considered, I have relied upon searches of the digital versions of the works in question as given in GRETIL, the Göttingen Register of Electronic Texts in Indian Languages: http://gretil.sub.uni-goettingen.de/. Although the root form of khya is conserved with a high degree of stability in both conjugational forms and nominal derivatives, some possibilities of statistical error remain due to the occurrence of occasional false positives (e.g., when there are instances of words such as mukhyāt, or saukhyāt), as well as in cases in which khyā may not have been found owing to the effects of sandhi, e.g., samkhya $+i t i$. Though such occurrences are not sufficiently frequent so as to vitiate the observations proposed here, the numbers of global occurrences of $k h y \bar{a}$ and its derivatives stated for each text should be nevertheless taken as subject to a small margin of error.

${ }^{50}$ Buescher (2007): 130 (ad Trmís 25ab): ataś ca yathā prakhyāti tathāsyotpattir nāstīty

ato 'syotpattinihsvabhāvatety ucyate. "Hence, its [the heteronomous nature's] arising is not as it appears, wherefore it is said to be "without substantial being in its arising'." Though lexically unexceptional, the context, concerning the nihsvabhāvatā of the heteronomous nature, is of much interest here, as will be seen below.

${ }^{51}$ Text in Dutt (1978): 181. Trans. A. Engle in Asanga (2016): 442.

${ }^{52}$ Most of the occurrences of khyā in the relevant sense in the MSA(Bh) are in fact bundled together in just two passages: 11.38-39 and 19.53-55 including their commentaries.

${ }^{53}$ Lévi (1907): v. 2, p. 117.

${ }^{54}$ Maitreyanātha/Āryāsanga (2004): 131-132.

${ }^{55}$ One notes in this respect a parallel with later Kashmir Śaiva usage. See, e.g., Bansat-Boudon and Tripathi (2011): 174, n. 760, where khyāti is taken in the sense of pratyabhijña $\bar{a}$, the "recognition" through which the supreme self is disclosed.

${ }^{56}$ Suzuki (1932): 33 renders this as "perceiving Vijñāna" and in (1930): 190 explains that "this function of the Vijñāna is to perceive or reflect things that appear before it just as the mirror reflects all forms before it....[I]t is pure and undefiled, which means that it is free from the dualism of subject and object." On the basis of Suzuki's discussion, Edgerton (1953): 207 defines it as "pure perception." I think, however, that this is somewhat misleading; so far as I understand the usage of the LAS, khyātivijñāna emerges from the vāsanās, the latent dispositions implanted in the ālayavijñāna - Suzuki himself says as much—and therefore cannot be "pure and undefiled" if by this one means exempt from karman and kleśa. Cf. Suzuki (1932): 43: "the perceiving Vijñāna functions because of transformation's (sic!) taking place [in the mind] by reason of a mysterious habit-energy." Exactly what Suzuki meant by introducing the phrase "pure and undefiled" in this context is not quite clear.

${ }^{57}$ The plan for this section of the work is set out in TSN 10: sadasattvād dvayaikatvāt samkleśavyavadānayoh / 
lakșaṇābhedataś ceștā svabhāvānām gambhīratā // "The profundity of the [three] natures is affirmed by reason of being and nonbeing, duality and unicity, affliction and purification, and the indivisibility of the [three] modes."

${ }^{58}$ It may be remarked that the causative use of khyā in this passage, meaning "to make known," is consistent in the diction of the author of the MAVBh; he never uses this verb or its derivatives in the meaning "to appear." Sthiramati, however, in his $t \bar{l} k \bar{a}$ on the MAVBh, writes in chapter three: yat khyāti māyopadānavat tad asti yathā khyātii grāhyagrāhakākāreṇa naitad evam | "what appears, like the occurrence of an illusion, exists, [but] not so the manner in which it appears phenomenally as object and subject" (Yamaguchi 1934: 113, lines 12-14). I am grateful to Hartmut Buescher for this observation.

${ }^{59}$ I am speaking here of the verse texts ascribed to Vasubandhu, chiefly the ADhK. Some examples of substitution patterns may be found in his prose, for instance in the relatively frequent use of the catușoți framework in the ADhKBh. But even here we do not find patterned stylistic repetition of the kind we see in TSN.

${ }^{60}$ The remarkable inconsistency of this verse with TSN 16 was perhaps what led Mukhopadhyaya (1939) to emend the first pāda of verse 16 to read: dvayābhāvasvabhāvatvād, "owing to its nondual nature ..." No doubt he also had 19b, dvayābhāvasvabhāvatah, in mind in making this emendation. The manuscript, in any case, supports the reading dvayabhāva- in verse 16, and the inconsistency of this with both verses 13 and 19 must be counted as yet another problematic aspect of the TSN.

${ }^{61}$ Refer to Kapstein (1988).

${ }^{62}$ We may remark, too, that MSA 11.27 explicitly considers the conjunction of being and nonbeing to be characteristic of error: sadasanto 'tha māyābhā ye dharmā bhrāntilakșaṇāh. Moreover, as is well know, the third lemma of the catuskoți in Madhyamaka is precisely the conjunction of mutually exclusive alternatives, and for that reason is excluded.

${ }^{63}$ An objection to this has been anticipated by Garfield, who has suggested to me that the discrepancies between the Trmś and the TSN might be comparable to the shift from the early to the later works of Ludwig Wittgenstein, whose change of perspective is well known to students of contemporary philosophy. While I agree with Garfield that we must avoid the untenable supposition that thinkers must be self-consistent throughout their entire careers - in the case of Vasubandhu the kośakāra we know that he espoused a variety of viewpoints even without taking account of the TSN-I do not think that this has much bearing in the present instance. For if the author of the Trmś, presumably the kośakāra, had changed his thinking about the three natures late in his career and had written a treatise, the TSN, documenting this, can we really imagine that no one would have taken notice? Once again, the puzzle of Xuanzang, who studied ten commentaries on the Trmś and was familiar with oral traditions about it at Nālandā, must be born in mind. After all, no one who has attended seminars on Wittgenstein and read some scholarship about him can have failed to notice that there was an important break separating the Tractatus from the Philosophical Investigations.

${ }^{64}$ McNamara (2011) has not been published, but has been made available on the internet by the author.

${ }^{65}$ Lamotte (1973 [1938]); Sponberg (1983). See also D’Amato (2005).

${ }^{66}$ My reading of the Sanskrit text of TSN 32c-upalambhānimagnas tu-differs from the reading proposed in the three original and all subsequent editions: upalambhaipnagnastu emended to upalambho 'saddvayas tu (Yamaguchi [1931]); upalambho' nimittas tu (La Vallée Poussin [1933]); upalambhanimittā tu (Mukhopadhyaya [1939]). In proposing this correction, I follow the published facsimile of the surviving manuscript: Mimaki et al. (1989), plate 3, folio 2b, line 6.

${ }^{67}$ Trmś 23ab: trividhasya svabhāvasya trividhām nihsvabhāvatām. The three types of insubstantiality specified in verses 24-25ab are: insubstantiality of signs, corresponding to the conceptually constructed; insubstantiality of origination, corresponding to the heteronomous; and insubstantiality of ultimate reality, corresponding to the consummate.

${ }^{68}$ Trmś 29-30.

69 The first pāda is perhaps better read: viruddhadhīvāranatvād, "owing to the obstruction of opposing ideas." In the second pāda, vaiyarthya may indeed mean "objectlessness" in this context, but the term is more readily taken as "purposelessness, insignificance." The jñannatraya of the third pāda may refer to the three phases of

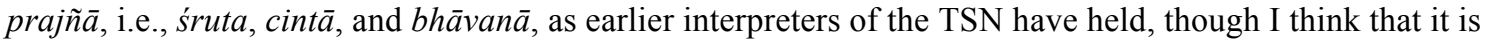
equally plausible to see here a reference to LAS, pp. 49-50, on the "three characteristics of sublime gnosis" (äryajñ̄analakșaṇatraya): nirābhāsalakșaṇa, sarvabuddhasvapraṇidhānādhișthānalakșaṇa, and pratyātmāryajñānagatilakșaṇa. See, too, Suzuki (1930): 140, (1932): 45.

${ }^{70}$ An example is Sthiramati's use of the phrase when he writes, referring to Vasubandhu's Pañcaskandhaka: sañkșepena dharmalakșanavyutpannā ayatnena dharmalakșanavistarapratipattisamarthä bhavișanti (Kramer 2013: 1), "those competent in the characteristics of the principles in brief will easily become capable of mastery of the characteristics of the principles at length." But evidently he is not speaking here of liberation. Cf., However, in a Madhyamaka context, Āryadeva, Catuhśataka 8.22: iha yadyapi tattvajño nirvāṇam 
nādhigacchati/ prāpnoty ayatnato 'vaśyam punarjanmani karmavat//"Here [= in this lifetime], although the knower of reality attains not nirvana, he certainly obtains it without effort in a future lifetime, like karma."

${ }^{71}$ E.g., the Mahāyānottaratantraśāstropadeśa by Sajjana, one of the Kashmiri Candrakīrti's compatriots and contemporaries, edited in Takasaki (1975).

${ }^{72}$ Given the broad diffusion of this example in Buddhist literature, as we have seen, this by no mean demonstrates a particular affinity of these two texts. The relevant passage in the *Madhyamakaprajñāvatāra, lines 11-14, reads as follows: snang ba'i dngos po 'di yang ni// yang dag pa yi rang bzhin med// du ma dang ni gcig bral phyir// sgyu ma'i glang po ji bzhin no//. "As for these apparent entities, they are without genuine essence. Because they are free from many and one, they are just like the illusory elephant." Note, too, the author's interest in the problem of one and many.

${ }^{73}$ Nāgārjuna, Āryadeva, and Candrakīrti figure among the patriarchs of the so-called "Ārya" tradition of the Guhyasamājatantra. Dharmakīrti occurs as the name of one of Atiśa's teachers during the eleventh century. The Tattvasiddhi attributed to a Śāntarakșita appears to be a late work not at all by the celebrated eighth-century philosopher of the same name. And Kamalaśîla is given as the proper name of "Holy Father Buddha" (pha dampa sangs-rgyas), a South Indian Buddhist yogī who attracted a later following in late-eleventh - early-twelfthcentury Tibet.

${ }^{74}$ Refer to n. 9 above.

${ }^{75}$ Isaacson (2013).

${ }^{76}$ Thus, for instance, Utpaladeva characterizes his İ́varapratyabhijñā as janasyāyatnasiddhyartham, "in order that the ordinary man too can attain perfection effortlessly" (Torella 1994: 81 [text], 219 [translation]).

${ }^{77}$ Collingwood (1993): 7. He unpacks this in writing (444): "The historian ... re-enacts the past in his mind: but in this re-enactment it does not become a present or an actuality. The actuality is the actual thought of the historian that reenacts it. The only sense in which the object of historical thought is actual, is that it is actually thought about. But this does not confer any kind of actuality upon it, taken in itself. It remains wholly ideal." ${ }^{78}$ Pertinent contributions include Harris (1991), Eckel (2008), Garfield and Westerhoff (2015). (The TSN figures prominently only in the latter.) The problem itself was, of course, one of the central points of contestation in Tibetan Buddhism, but in the present context that complex history, on which much has been written in recent years, may be left to one side.

On behalf of all authors, the corresponding author states that there is no conflict of interest.

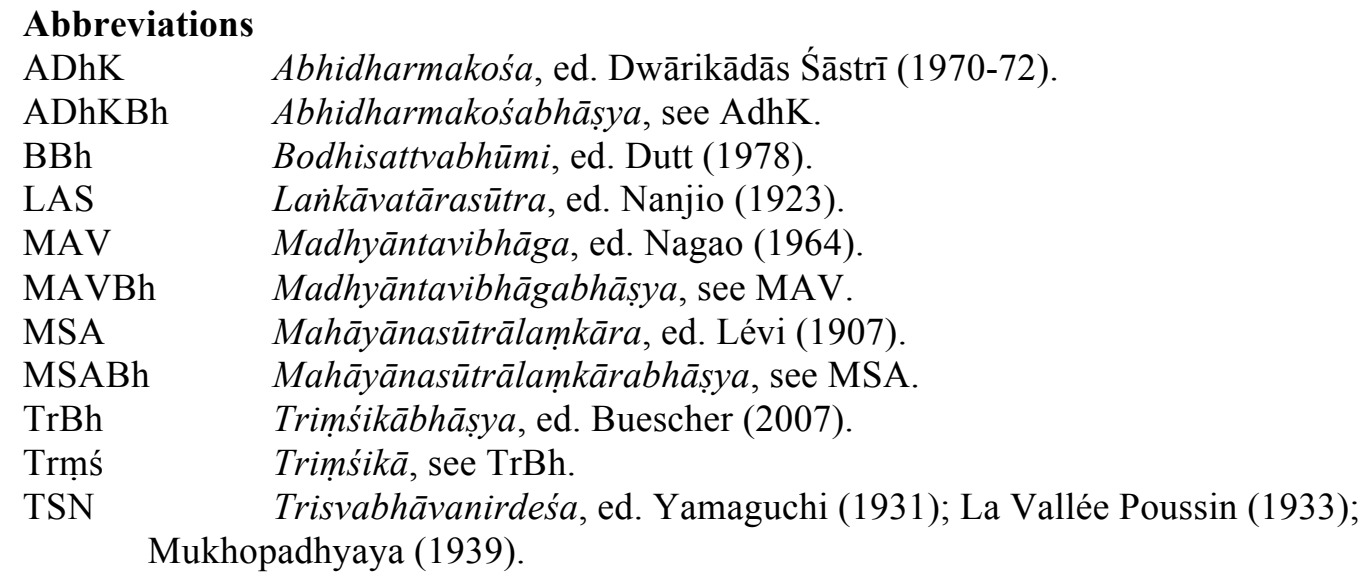

\section{References}

Anacker, Stefan (2005). Seven Works of Vasubandhu, the Buddhist Psychological Doctor. 2nd ed. Religions of Asia series. Delhi: Motilal Banarsidass.

Asanga (2016). The Bodhisattva Path to Unsurpassed Enlightenment: A Complete Translation of the Bodhisattvabhūmi. Trans. by Artemus B. Engle. Boulder, CO: Snow Lion. 
Bansat-Boudon, Lyne, and Kamaleshadatta Tripathi (2011). An Introduction to Tantric Philosophy: The Paramārthasāra of Abhinavagupta with the Commentary of Yogarāja. Routledge Studies in Tantric Traditions. London: Routledge.

Bhațtācārya, Tārānātha Vācaspati (1873). Vācaspatyam. Calcutta: Kavya Prakasha Press.

Böhtlingk, Otto and Rudolph Roth (1855). Sanskrit Wörterbuch, herausgegeben von der kaiserlichen Akademie der Wissenschaften. St. Petersburg: Eggers.

Boquist, Åke (1993). Trisvabhāva: A Study of the Development of the Three-nature-theory in Yogācāra Buddhism. Lund Studies in African and Asian Religions 8. Lund, Sweden: Department of History of Religions, University of Lund.

Brunnhölzl, Karl (2007). Straight from the Heart: Buddhist Pith Instructions. Ithaca: Snow Lion.

Bu ston, Rin-chen-grub (1988). Bu-ston-chos-'byung. Beijing: Krung-go Bod-kyi shes-rig dpe-skrunkhang.

Buescher, Hartmut (2007). Sthiramati's Trimśikāvijñaptibhāṣya: Critical Editions of the Sanskrit Text and its Tibetan Translation. Vienna: Österreichischen Akademie der Wissenschaften.

- (2013). "Distinguishing the Two Vasubandhus, the Bhāṣyakāra and the Kośakāra, as VijñānavādaYogācāra Authors." In: The Foundation for Yoga Practitioners. Ed. by Ulrich Timme Kragh, pp. 368-396.

Carpenter, Amber D. (2014). Indian Buddhist Philosophy. Durham: Acumen.

Chatterjee, Ashok Kumar (1971). Readings on Yogācāra Buddhism. Varanasi: Centre of Advanced Study in Philosophy, Banaras Hindu University.

Chattopadhyaya, Debiprasad, ed. (1981). Tāranātha's History of Buddhism in India. Trans. by Lama Chimpa and Alaka Chattopadhyaya. Atlantic Highlands, N.J.: Humanities Press.

Chogḍub, Thubtan and Rāmaśan̉kara Tripāṭhī (1972). Vijñaptimātratāsiddhi-prakaranadvayam. Gan̉gānāthajhā-granthamālā. Vārāṇasyām: Research Institute, Varanaseya Sanskrit Vishvavidyalaya.

Collingwood, R. G. (1993). The Idea of History. Ed. by Jan van der Dussen. Rev. ed. Oxford: Clarendon Press.

Cornu, Philippe (2008). Vasubandhu: Cinq traités sur l'esprit seulement. Tresors du bouddhisme. Paris: Fayard.

D’Amato, Mario (2005). “Three Natures, Three Stages: An Interpretation of the Yogācāra Trisvabhāva-Theory." In: Journal of Indian Philosophy 33, pp. 185-207.

Dutt, Nalinaksha, ed. (1978). Bodhisattvabhūmih . Bhoțadeśīya-Saṃskṛta-granthamālā. Pāțaliputram: Kāśīprasāda-Jāyasavāla-Anuśîlanasaṃsthānaṃ.

Dwārikādās Śāstrī, Swāmī, ed. (1970-72). Vasubandhu, Abhidharmakośam, 4 vols. Varanasi: Bauddha Bharati.

Eckel, Malcolm David (2008). Bhāviveka and his Buddhist opponents: chapters 4 and 5 of Bhāviveka's Madhyamakahṛdayakārikah with Tarkajvāla commentary. Harvard Oriental Series. Cambridge, Mass.: Dept. of Sanskrit and Indian Studies, Harvard University.

Edelglass, William and Jay L. Garfield, eds. (2009). Buddhist Philosophy: Essential Readings. New York: Oxford University Press.

Edgerton, Franklin (1953). Buddhist Hybrid Sanskrit Dictionary. New Haven: Yale University Press.

Frauwallner, Erich (1951). On the Date of the Buddhist Master of the Law Vasubandhu, Rome: Istituto Italiano per il Medio ed Estremo Oriente.

Garfield, Jay L. (1997). "Vasubandhu's Treatise on the Three Natures translated from the Tibetan edition with a commentary." In: Asian Philosophy 7.2, pp. 133-154.

- (2002). Empty Words: Buddhist Philosophy and Cross-Cultural Interpretation. New York: Oxford University Press.

- (2015). Engaging Buddhism: Why it matters to philosophy. New York: Oxford University Press.

Garfield, Jay L. and Jan Westerhoff, eds. (2015). Madhyamaka and Yogacara: Allies or Rivals? New York: Oxford University Press.

Gold, Jonathan C. (2015). Paving the Great Way: Vasubandhu's Unifying Buddhist Philosophy. New York: Columbia University Press.

Han Jingqing 韩镜清 (1998). Cishixue jiu zhong yi zhu 慈氏學九種譯著, Zhongguo fojiao wenhua yanjiusuo bian 中國佛敎文化研究所編. Xianggang: Zhongguo fojiao wenhua chuban 
youxian gongsi 香港: 中國佛敉文化出版有限公司, 1998, pp 57-96.

Harris, Ian Charles (1991). The Continuity of Madhyamaka and Yogācāra in Indian Mahāyāna Buddhism. Brill's Indological Library 6. Leiden: E.J. Brill.

Herrmann-Pfandt, Adelheid (2007). Die Lhan Kar Ma: ein früher Katalog der ins Tibetische übersetzten buddhistischen Texte. Vienna: Österreichischen Akademie der Wissenschaften.

Horiuchi, Toshio (2009). "Vasubandhu's Relationship to the Mahāyānasūtrālaṃkārabhāṣya and Lañkāvatārasūtra Based on Citations in the Vyākhyāyukti." In: Studies in Philosophy 34, pp. 101-108.

Isaacson, Harunaga (2013). "Yogācāra and Vajrayāna according to Ratnākaraśānti." In: The Foundation for Yoga Practitioners. Ed. by Ulrich Timme Kragh, pp. 1036-1051.

Jhalakīkar, Mahāmahopadhyāya Bhīmācārya (1978). Nyāyakośa or Dictionary of Technical Terms of Indian Philosophy. 3rd. Bombay Sanskrit and Prakrit Series XLIX. Poona: Bhandarkar Oriental Research Institute.

Jaini, Padmanabh (1958). "On the Theory of Two Vasubandhus". Bulletin of the School of Oriental and African Studies (1): 48-53.

Jin Kemu 金克木 (2008). Zangwai Fojiao Wenxian 藏外佛教文献, vol. 10, ed. Fang Guangchang 方 廣錩. Beijing: Zhongguo Renmindaxue chubanshe 中国人民大学出版社, pp. $3 \mathrm{ff}$.

Liu Xiaolan 劉孝蘭 (1986). 三自性論 in Lan Jifu 藍吉富, ed., Dazangjing bubian 大藏經補編, vol. 9 (Taipei: Huayü chubanshe, 1986). Electronic version (accessed 9/8/2017): http://cbetaonline.dila.edu.tw/zh/B0036_001.

Kapstein, Matthew T. (1988). “Mereological Considerations in Vasubandhu's 'Proof of Idealism'.” In: Idealistic Studies 1988.1, pp. 32-54.

Kataoka, Kei (2017). "A Critical Edition of the Khyāti Section of the Nyāyamañjarī: Bhaț̣a Jayanta on Akhyāti and Viparìtakhyāti." In: Bulletin of Institute of Oriental Culture 171, pp. 476-401.

Kochumuttom, Thomas A. (1982). A Buddhist Doctrine of Experience : a New Translation and Interpretation of the Works of Vasubandhu, the Yogācārin. Delhi: Motilal Banarsidass.

Kragh, Ulrich Timme, ed. (2013). The Foundation for Yoga Practitioners : the Buddhist Yogācārabhūmi Treatise and Its Adaptation in India, East Asia, and Tibet. Harvard oriental series 75. Cambridge, Mass.: Harvard University Department of South Asian Studies.

Kramer, Jowita (2013). Sthiramati's Pañcaskandhakavibhāṣa, Part I: Critical Edition. Sanskrit Texts from the Tibetan Autonomous Region 16/1. Beijing/Vienna: China Tibetology Publishing House/Austrian Academy of Sciences.

- (2016). "Some Remarks on Sthiramati and his Putative Authorship of the Madhyāntavibhāgațikka , the *Sütrālaṃkāravrttibhāṣya, and the Triṃśatikāvijñaptibhāṣya." In: Buddhist Studies Review (33.1-2), pp. 47-63.

Kumar, Mahendra (1938). Nyāyakumuda-candra of Śrīmat-Prabhācandrācārya. Vol. 1. Māniikcandra Digamabara Jain Granthamālā XXXVIII. Bombay.

La Vallée Poussin, Louis de (1933). "La petit traité de Vasubandhu-Nagarjuna sur les trois natures." In: Mélanges chinois et bouddhiques. Vol. 2, pp. 147-161.

Lamotte, Étienne (1973). La Somme du Grand Véhicule d'Asañga (Mahāyānasamgraha). 2 vols. Publications de l'Institut Orientaliste de Louvain 8. Louvain: Institut Orientaliste.

Lévi, Sylvain (1907). Mahāyāna-Sūtrālaṃkāra, exposé de la doctrine du Grand Véhicule selon le système Yogācāra. Bibliothèque de l'École des hautes études. Sciences historiques et philologiques. Paris: H. Champion.

Lo-yag-bkra-shis, Mtshur-phu mkhan-po, ed. 2006. Karma-pa Rang-byung-rdo-rje'i gsung-'bum. 16 vols. Xining: Mtshur-phu mkhan-po Lo-yag-bkra-shis.

Lusthaus, Dan (2002). Buddhist Phenomenology: A Philosophical Investigation of Yogācāra Buddhism and the Ch'eng Wei-shih lun. Curzon Critical Studies in Buddhism. London: RoutledgeCurzon.

Maitreyanātha/Āryāsañga (2004). The Universal Vehicle Discourse Literature: Mahāyānasūtrālamkāra. Trans. by L. Jamspal et al. Treasury of the Buddhist Sciences Series. New York: American Institute of Buddhist Studies.

McNamara, Daniel (2011). "On the Status of the Trisvabhāvanirdeśa in Contemporary Conceptions of Yogācāra Thought.” URL: http://www.academia.edu/8365343/. 
Mimaki, Katsumi, Musashi Tachikawa, and Akira Yuyama, eds. (1989). Three works of Vasubandhu in Sanskrit manuscript: the Trisvabhāvanirdeśa, the Vimiśatika with its Vrtti, and the Trimsisika with Sthiramati's commentary. Bibliotheca codicum Asiaticorum. Tokyo, Japan: Centre for East Asian Cultural Studies.

Monier-Williams, Monier (1956). A Sanskrit-English Dictionary etymologically and philologically arranged with special reference to cognate Indo-European languages. Oxford: Clarendon Press.

Mukhopadhyaya, Sujitkumar, ed. (1939). The Trisvabhāvanirdeśa of Vasubandhu: Sanskrit text and Tibetan versions. Visvabharati Studies 4. Calcutta: Visvabharati.

Nagao, Gadjin M. 長尾雅人, ed. (1964). Madhyāntavibhāga-bhāṣya: A Buddhist Philosophical Treatise Edited for the First Time from a Sanskrit Manuscript. Tokyo: Suzuki Research Foundation.

— trans. (1976). “Sanseiron [Trisvabhāvanirdeśa]” in Seshin Ronshū 世親論集 [Works of Vasubandhu]. Tokyo: Chūōkōronsha.

Nakamura, Hajime (1987). Indian Buddhism: A Survey with Bibliographical Notes. Indian edition. Delhi: Motilal Banarsidass.

Ñāṇamoli, Bhikkhu (1980). A Thinker's Note Book: Posthumous Papers of a Buddhist Monk. Ed. by Nyanaponika. 2nd ed. Kandy: Buddhist Publication Society.

Nanjio, Bunyiu. ed. (1923). The Lañkāvatārasūtra. Kyoto: Otani University Press.

Obermiller, Eugéne (1931). History of Buddhism (Chos-hbyung) by Bu-ston. Materialien zur kunde des buddhismus, 18.-19. hft. Heidelberg: In kommission bei O. Harrassowitz.

Phyogs-las-rnam-rgyal, Jo-nang (2010). Bstan-'gyur-dkar-chag. Jo-nang-dpe-tshogs (Jonang Publication Series) 23. Beijing: Mi-rigs-dpe-skrun-khang.

Powers, John (1991). The Yogāeāra School of Buddhism: A Bibliography. ATLA Bibliography Series. Metuchen, N.J.: The Scarecrow Press.

Rahder, Johannes (1926). “Daśabhūmika-Sūtram. Seventh Stage.” In: Acta Orientalia 4, pp. 214-256.

Rao, Srinivasa (1998). Perceptual Error: The Indian Theories. Society for Asian and Comparative Philosophy Monograph 16. Honolulu: University of Hawai'i Press.

Rig-pa'i-ral-gri, Bcom-ldan (2009). Dbu-ma-rgyan-gyi rnam-par-bshad-pa tshig-don gsalba 'i me-tog. Ed. by Bde-legs-rab-rgyas. Rnam-grol 'dod-'jo ris-med dpe-rnying-khang-gi tshad-ldan ngesdon dpe-tshogs, vol. 6. Xining: Rnam-grol 'dod-'jo dpe-rnying-khang, pp. 415-454.

Roerich, George N. (1949). The Blue Annals. Calcutta: Asiatic Society of Bengal.

Sakuma, Hidenori S. (2013). "Remarks on the Lineage of Indian Masters of the Yogācāra School: Maitreya, Asanga, and Vasubandhu." In: The Foundation for Yoga Practitioners. Ed. by Ulrich Timme Kragh, pp. 330-366.

Schaeffer, Kurtis R. and Leonard W. J. van der Kuijp (2009). An Early Tibetan Survey of Buddhist Literature: The Bstan pa rgyas pa rgyan gyi nyi 'od of Bcom ldan ral gri. Harvard Oriental Series 64. Cambridge, Mass.: Harvard University Department of Sanskrit and Indian Studies.

Schmithausen, Lambert (1965). Mandanamiśra's Vibhramavivekah : mit einer Studie zur Entwicklung der indischen Irrtumslehre. Vienna: Österreichischen Akademie der Wissenschaften.

- (1987). Alayavijñana: On the Origin and the Early Development of a Central Concept of Yogācāra Philosophy. 2 vols. Studia Philologica Buddhica Monograph Series IVa-b. Tokyo: The International Institute for Buddhist Studies.

- (2014). The Genesis of Yogācāra-Vijñānavāda: Responses and Reflections. Kasuga Lectures Series I. Tokyo: The International Institute for Buddhist Studies.

Skilling, Peter (2000). "Vasubandhu and the Vyākhyāyukti Literature." In: Journal of the International Association of Buddhist Studies 23.2, pp. 297-350.

Sponberg, Alan (1983). “The Trisvabhāva doctrine in India and China.” In: Ryūkoku Daigaku Bukkyō Bunka Kenkyüjo Kiyō 22, pp. 97-119.

Sugawara, Yasunori (1996). 世親『三性論』の撰述に関する疑問 “Der Zweifel am Autor von 'Trisvabhāva-nirdeśa' (in Japanese).” In: 文化 Bunka 60, pp. 108-127.

Suzuki, Daisetz Teitaro (1930). Studies in the Lankavatara Sutra. London: Routledge \& Kegan Paul. - (1932). The Lankavatara Sutra: A Mahayana Text. London: Routledge \& Kegan Paul. 
Takasaki, Jikidō (1975). “A Manuscript of the Mahāyānottaratantraśāstropadeśa, a Sanskrit Commentary on the Ratnagotravibhāga." In: Journal of Indian and Buddhist Studies XXIII.2, pp. 1065-1057.

Tāranātha, Jo-nang rje-btsun (2004). Shes-rab-kyi pha-rol-tu phyin-pa'i snying-po 'i mdo rnam-parbshad-pa sngon-med legs-bshad. Thub-bstan e-wam dpe-tshogs 1. Lhasa: Bod-ljongs midmangs dpe-skrun-khang, pp. 30-184.

Tola, Fernando and Carmen Dragonetti (1983). "The Trisvabhāvakārikā of Vasubandhu.” In: Journal of Indian Philosophy 11, pp. 225-266.

- (1989). El idealismo budista: la doctrina de 'solo-la-mente'. Mexico City: Premia.

- (2004). Being as Consciousness : Yogācāra Philosophy of Buddhism. New Delhi: Motilal Banarsidass.

Torella, Raffaele (1994). The Íśvarapratyabhijñākärikā of Utpaladeva with the Author's Vrtti. Serie Orientale Roma LXXI. Rome: Istituto Italiano per il Medio ed Estremo Oriente.

Wood, Thomas E. (1991). Mind Only: A Philosophical and Doctrinal Analysis of the Vijñannavāda. Monographs of the Society for Asian and Comparative Philosophy 9. Honolulu: University of Hawaii Press.

Yamaguchi, Susumu (1931). "Trisvabhāvanirdeśa of Vasubandhu, Skt. text and Japanese translation with annotation." In: Shükyo kenkyū (Journal of Religious Studies). New Series 8.2, pp. 121130, 186-207.

- (1934). Madhyāntavibhāgaț̄ikā. Nagoya: Hajinkaku.

- (1972). Yamaguchi Susumu Bukkyōgaku bunshū. 3 vols. Tōkyō: Shunjūsha. 